\title{
Archean and Paleoproterozoic crust of the São Francisco Craton, Bahia, Brazil: geodynamic features
}

\author{
J.S.F. Barbosa ${ }^{a, *}$, P. Sabaté ${ }^{b, 1}$ \\ ${ }^{\text {a } C P G G-C e n t r o ~ d e ~ P e s q u i s a ~ e m ~ G e o f i ́ s i c a ~ e ~ G e o l o g i a / U F B A, ~ R u a ~ C a e t a n o ~ M o u r a, ~} 123$ Federação, 40210-340 Bahia, Brazil \\ ${ }^{\mathrm{b}}$ IRD—Representation in Brazil CP7091, Lago Sul, 71619-970 Brasilia, DF, Brazil
}

Received 30 July 2002; accepted 9 March 2004

\begin{abstract}
Recent geological, geochronological and isotopic studies allow the identification of four important crustal segments in the basement of the São Francisco Craton in Bahia. The oldest is the Gavião block in the WSW part of the studied area, and comprises granitic, granodioritic and migmatitic continental crust including remnants of $3.4 \mathrm{Ga}$ TTGs which are amongst the oldest rocks in South America, and are associated with Archean greenstone belts. The youngest segment is exposed in the Itabuna-Salvador-Curaça belt which extends from SE Bahia along the Atlantic coast to Salvador, then northwards into NE Bahia. It is mainly composed of a low-K calc-alkaline plutonic suite, and also contains strips of intercalated metasediments and ocean floor/back-arc basin gabbro and basalt. In the SSW part of the area the Jequié block comprises granulitic migmatites with inclusions of supracrustal rocks, intruded by many charnockite plutons. In the NE, the Serrinha block is composed of orthogneisses and migmatites which form the basement for Paleoproterozoic greenstone belts. During the Paleoproterozoic Transamazonian Cycle, these four crustal segments collided, resulting in the formation of an important mountain belt. The regional metamorphism, resulting from the crustal thickening associated with the collision, occurred at around $2.0 \mathrm{Ga}$. Major mineralizations were formed during the evolution of the four Archean blocks, and also during and after the Paleoproterozoic collision.
\end{abstract}

(C) 2004 Elsevier B.V. All rights reserved.

Keywords: Geochemical; Geocronological; Geotectonic models; Mineral deposits; Bahia; Brazil

\section{Introduction}

The essential features of the terrains which compose the São Francisco Craton are all found in Bahia, occupying the eastern part of the state which is encircled by the river which lends its name to the

\footnotetext{
* Corresponding author. Tel.: +55-71-2038606; fax: +55-71-2038501.

E-mail addresses: johildo@cpgg.ufba.br (J.S.F. Barbosa), pierre.ird@apis.com.br (P. Sabaté).

1 Tel.: +55-61-2485378.
}

craton. Here, the largest remains of Archean and Paleoproterozoic terrains of the Brazilian Shield are preserved.

In this paper we combine the abundant and precise data on this region which have been obtained during the last 10 years. These studies have shown that the older basement, mainly composed of medium to high-grade metamorphic rocks but with smaller areas of low-grade rocks of the greenstone belts, underlies about $50 \%$ of the total area of the craton. We present the mosaic of protocontinents or Archean continental fragments which form the Gavião, 
Jequié, Itabuna-Salvador-Curaça and Serrinha blocks, and which participated in the collisions which gave rise to the Paleoproterozoic belts. These represent a well-preserved and well-studied example of an Orosinian $(2.05-1.85 \mathrm{Ga})$ orogen, although the structural and geochronological data on this orogen in Bahia show that a succession of events occurred from east to west between 2.20 and $1.80 \mathrm{Ga}$.

The approximate ages of rock formation and metamorphism are summarized in tables which list them in decreasing order. Ample use is made of geochemical discrimination diagrams, and geological sections referring to different phases of evolution of the craton, especially before and after the Paleoproterozoic collision, are also provided. Short descriptions of associated mineral deposits are given. Finally, we cite the correlations which exist between this Brazilian craton and the Congo-Gabon Craton in Africa, both of which are similar (REFS).

\section{Tectonic setting}

The São Francisco Craton (Almeida, 1977) is the best exposed and most easily accessible unit of the South America Platform, and of the Precambrian Brazilian Shield (Fig. 1). Its geophysically defined boundaries (Ussami, 1993) and the location of the surrounding Brasiliano/Pan-African fold belts show that it occupies most of Bahia (Fig. 1). The cratonic block, stable during the Brasiliano orogeny, has a cover formed by mainly undeformed Mesoproterozoic, largely siliciclastic, and Neoproterozoic, largely carbonate sediments. The Archean-Paleoproterozoic basement includes medium to high-grade metamorphic rocks and remnants of low-grade greenstone belts, all intruded by Paleoproterozoic granite, syenite and rare mafic-ultramafic plutons.

The following geotectonic units which form the basement to the São Francisco Craton in Bahia are recognized (Barbosa and Dominguez, 1996; Fig. 2)

- The Gavião block (Marinho, 1991; Martin et al., 1991; Santos Pinto, 1996; Cunha et al., 1996) is mainly composed of gneiss-amphibolite associations and amphibolite facies tonalite-granodiorite orthogneisses dated at ca. $2.8-2.9 \mathrm{Ga}$, as well as greenstone belts. There is also an old nucleus of trondhjemite-tonalite-granodiorite (TTG), which includes some of the oldest rocks in South America, with ages ranging from 3.4 to $3.2 \mathrm{Ga}$.

- The Serrinha block contains banded gneisses, amphibolites and orthogneisses mainly of granodiorite composition, with ages from about 2.9 to $3.5 \mathrm{Ga}$, all mainly in amphibolite facies (Padilha and Melo, 1991).

- The Archean $(3.2-2.9 \mathrm{Ga})$ greenstone belts of Contendas-Mirante, Umburanas, Riacho de Santana, and Mundo Novo are in the Gavião block, and the Palaeoproterozoic (2.0-2.1 Ga) Capim and Rio Itapicuru greenstone belts are located in the Serrinha block. Other, less well-known belts are also present. They are in greenschist facies, and are composed of komatiites with spinifex textures that pass upwards to mafic and felsic lavas with intercalations of pyroclastic rocks, and siliciclastic and chemical sediments (Marinho, 1991; Cunha and Fróes, 1994; Mascarenhas and Alves da Silva, 1994; Winge, 1984; Silva, 1992, 1996). Komatiites are rare in the Palaeoproterozoic greenstones.

- The Jequié block (Cordani, 1973; Barbosa, 1986, 1990; Barbosa and Sabaté, 2000) is mainly formed of enderbite and charnockite with ages of 2.7-2.6 Ga, as well as migmatite and granulite. The prevailing metamorphic grade is in the granulite facies.

- The Itabuna-Salvador-Curaçá belt, is in granulite facies. The Salvador-Curaça segment is exposed in northeast Bahia, while the Itabuna-Salvador segment occurs in the southeast. These segments are mainly formed of tonalite, charnockite with basic-ultrabasic enclaves, and less abundant supracrustal rocks (Barbosa, 1986, 1990; Padilha and Melo, 1991).

In this article, previously proposed tectonic relationships and tectono-stratigraphic subdivisions are re-evaluated in the light of new data obtained by Santos Pinto (1996), Bastos Leal (1998), Sato (1998), Correa Gomes (2000), Teixeira et al. (2000), Mello et al. (2000), Barbosa and Peucat (2004, in preparation), Barbosa et al. (2004, in preparation), amongst other sources, in an attempt to improve the knowledge of the geotectonic evolution of the basement of the São Francsico craton. The subdivision of the basement into the four major geological units, whose 


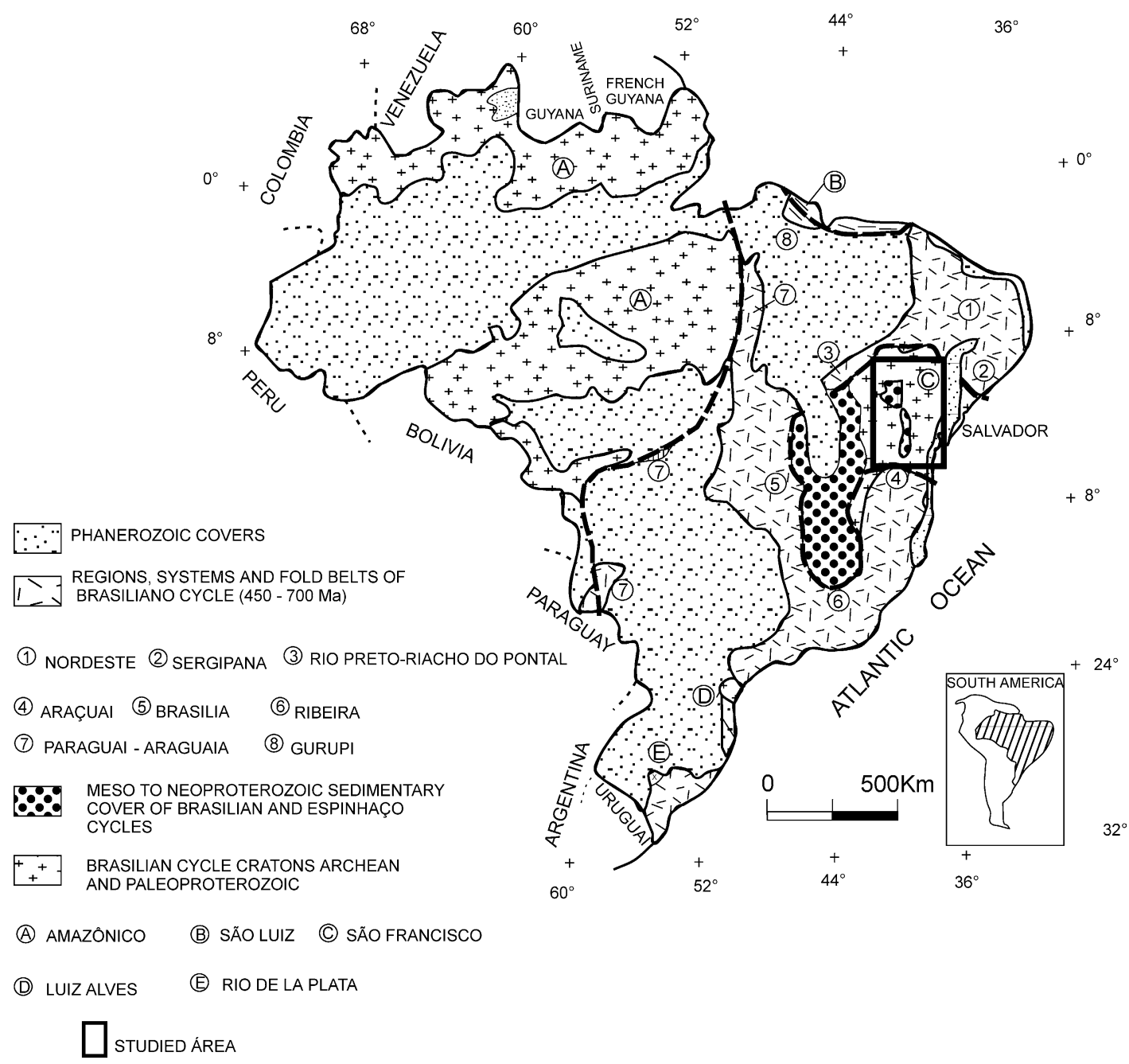

Fig. 1. Location of the cratons and Brazilian cycle fold belts (Almeida, 1977) in the studied area (Schobbenhaus et al., 1984).

limits are usually defined by vertical shear zones (Fig. 3), was maintained.

Each of these blocks has well-defined $\mathrm{Nd} T_{\mathrm{DM}}$ model ages (Fig. 3), and usually distinct fields in the $\varepsilon_{\mathrm{Nd}} \times \varepsilon_{\mathrm{Sr}}$ diagram, with values calculated for $t=2.0 \mathrm{Ga}$ (Fig. 4). $T_{\mathrm{DM}}$ model ages are older in the west and grow younger eastwards. This can be interpreted in terms of a crustal growth sequence. In Fig. 4, the Gavião block is the oldest and the Itabuna-Salvador-Curaçá belt, the youngest (Barbosa et al., 2000b). Not only do the isotopic data allow the separation of the blocks, but also their individual geologic features corroborate this separation.
For example, the Gavião block hosts only Archean greenstone belts, whereas the Serrinha block contains only Paleoproterozoic greenstone belts (Barbosa and Sabaté, 2000).

\section{The Gavião block}

In the southern part of the Gavião block (Fig. 3) two groups of tonalite-trondhjemite-granodiorite (TTG) plutonic rocks (Fig. 5) consitute an early continental crust in amphibolite grade (Marinho, 1991; Martin et al., 1991; Santos Pinto, 1996; Cunha et al., 1996; 


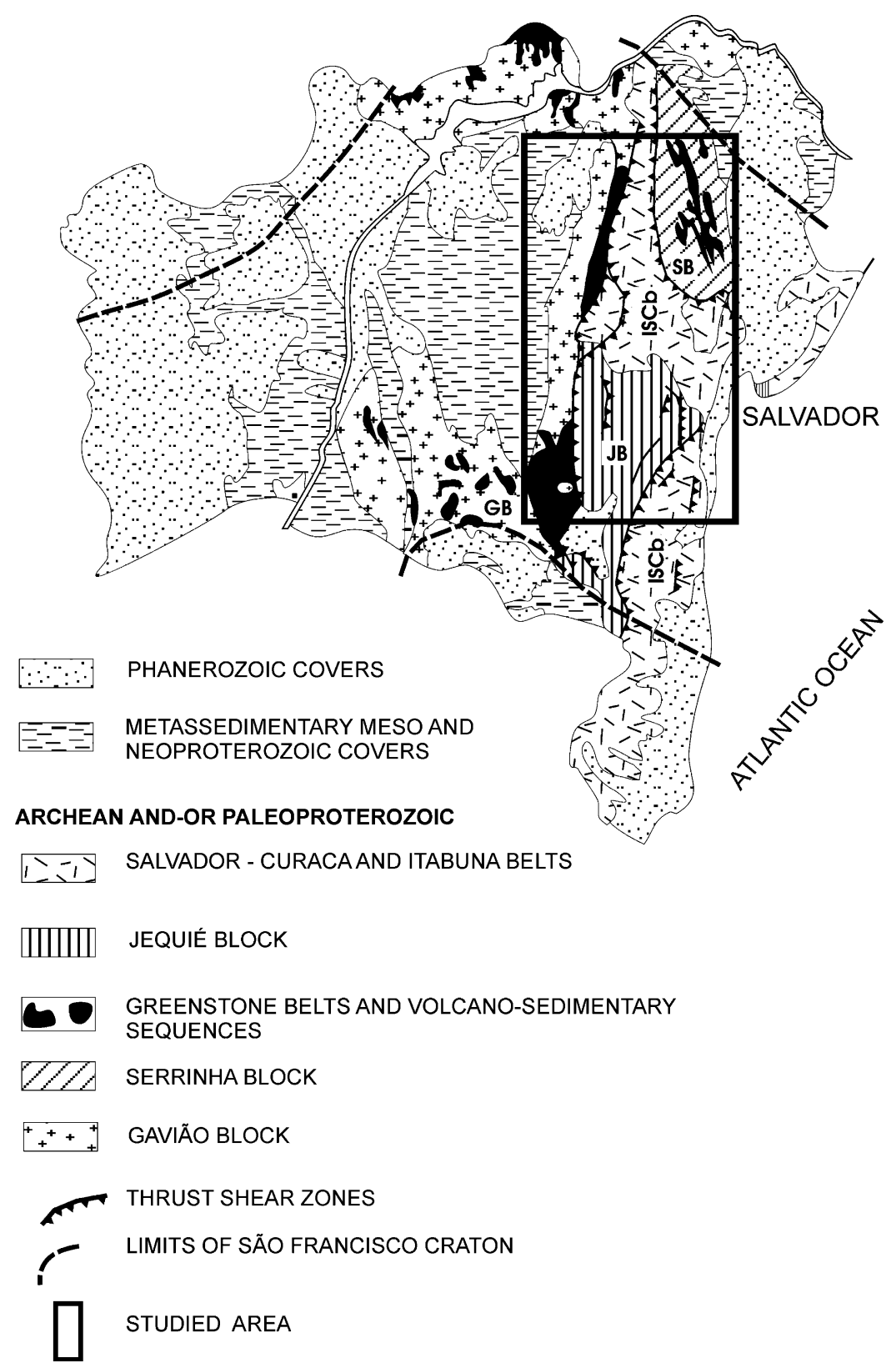

Fig. 2. Sketch map showing the boundaries and major structural units of the São Francisco Craton: (1) Archean/Paleoproterozoic basement with greenstone belts (black); (2) Mesoproterozoic units; (3) Neoproterozoic units; (4) Phaneorzoic covers; (5) limits of the craton; (6) Brazilian cycle fold belts; GB, Gavião block; JB, Jequié block; SB, Serrinha block; ISCb, Itabuna-Salvador-Curaça belt. Adapted from Alkmim et al. (1993). Rectangle shows the studied area. 


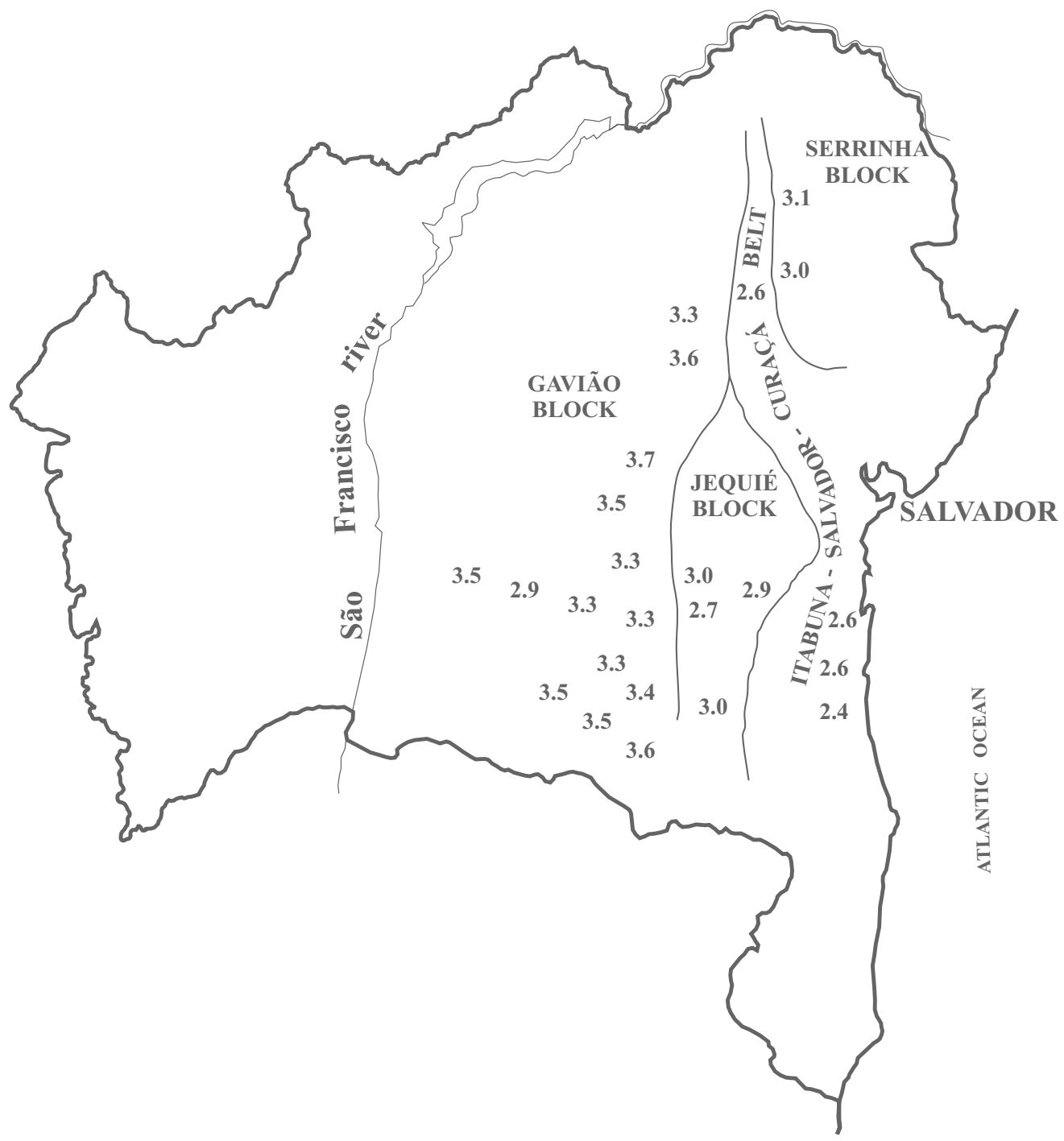

Fig. 3. Distribution of Archean and Paleoproterozoic Nd $T_{\mathrm{DM}}$ model ages in Bahia. Sources of data, see Tables 1-6.

Bastos Leal, 1998). The older grey gneisses with conventional $\mathrm{U}-\mathrm{Pb}$ zircon ages between 3.4 and $3.2 \mathrm{Ga}$ (Table 1) are considered to have originated through the partial melting of tholeiitic basalts, with garnet amphibolite or eclogite as the residue. The younger 3.2-3.1 Ga grey gneisses intruded the older rocks and were formed by partial melting of a pre-existing crust similar to the older gneisses by hydrous melting at a depth of approximately $30-45 \mathrm{~km}$ (Martin et al., 1997). In the southern part of the Gavião block, similar conditions were inferred for the formation of migmatites of TTG compostion. Preliminary single zircon $\mathrm{Pb}-\mathrm{Pb}$ age determinations for the Mairi migmatites yielded an age of $3034 \pm 6 \mathrm{Ma}$ (Peucat et al., 2002).

Several greenschist to amphibolite facies greenstone belts of the Gavião block (the best known being Contendas-Mirante, Umburanas, Brumado and Guajeru in the South, and Mundo Novo in the North) were probably formed in intracratonic basins overlying early TTG crust (Marinho, 1991; Mascarenhas and Alves da Silva, 1994; Cunha et al., 1996; Bastos Leal, 


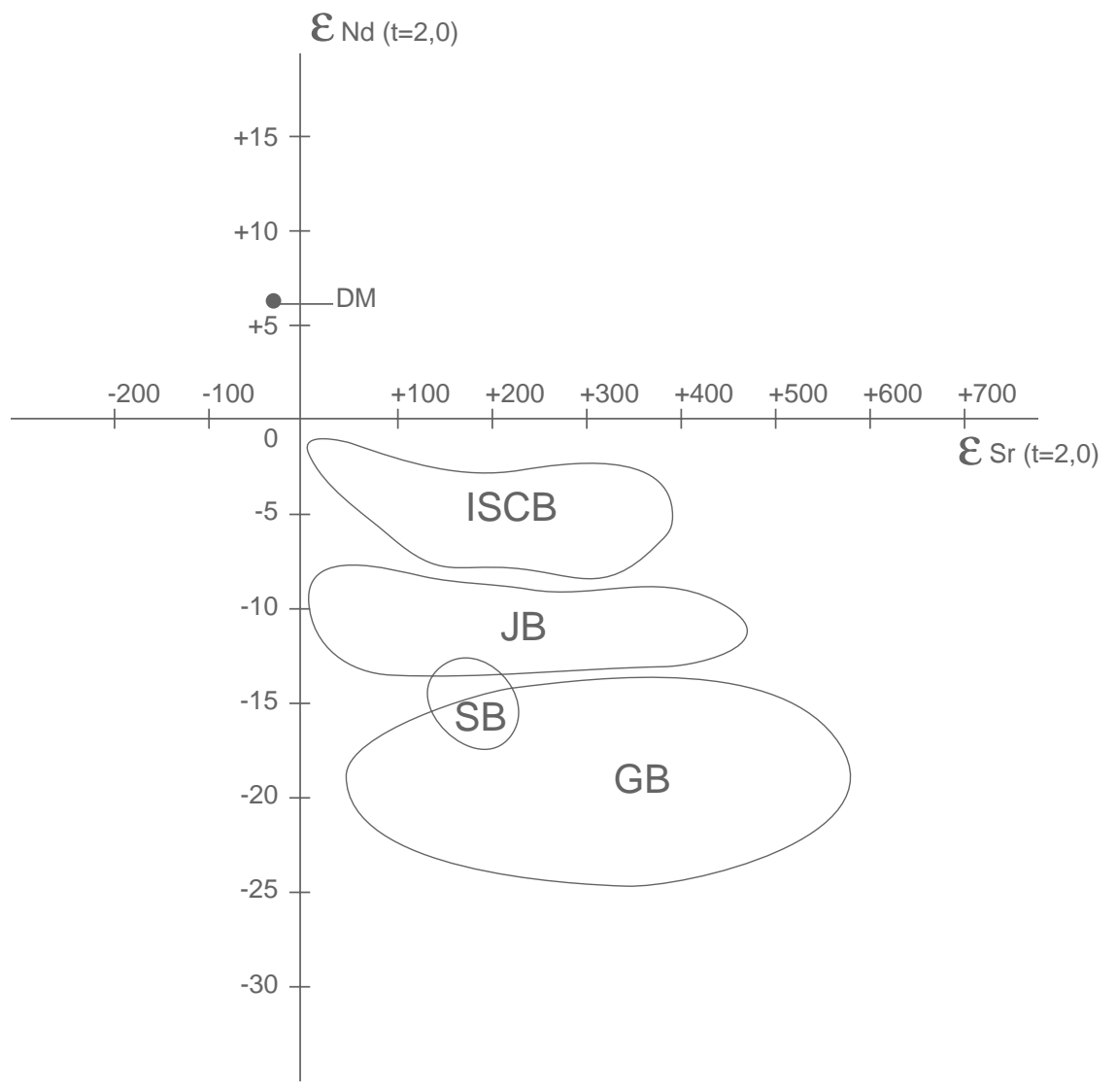

Fig. 4. $\varepsilon_{\mathrm{Nd}}$ vs. $\varepsilon_{\mathrm{Sr}}$ values modelled for $t=2.0 \mathrm{Ga}$, showing the distinct isotopic fields for each province. Values for the ISCB plot closest to DM (depleted mantle). Abbreviations as in Fig. 2.

Table 1

Gavião block

\begin{tabular}{|c|c|c|c|c|c|}
\hline Local & $\mathrm{Rb}-\mathrm{Sr}(\mathrm{Ma})$ & $\begin{array}{l}\mathrm{Pb}-\mathrm{Pb} \\
\mathrm{WR}(\mathrm{Ma})\end{array}$ & $\begin{array}{l}\mathrm{Pb}-\mathrm{Pb} \text { single } \\
\text { zircon }(\mathrm{Ma})\end{array}$ & $\begin{array}{l}\mathrm{U}-\mathrm{Pb} \text { zircon } \\
(\mathrm{Ma})\end{array}$ & $\begin{array}{l}T_{\mathrm{DM}} \\
(\mathrm{Ga})\end{array}$ \\
\hline $\begin{array}{l}\text { Sete Voltas TTG (Martin et al., 1991; Marinho, } \\
\text { 1991; Nutman and Cordani, 1993)) }\end{array}$ & $3420 \pm 90$ & & $3394 \pm 5$ & $3378 \pm 12^{*}$ & 3.6 \\
\hline $\begin{array}{l}\text { Boa Vista/Mata Verde TTG (Martin et al., 1991; } \\
\text { Marinho, 1991; Nutman et al., 1994) }\end{array}$ & $3550 \pm 67$ & $3381 \pm 83$ & & $3384 \pm 5^{*}$ & 3.5 \\
\hline Bernarda tonalite (Santos Pinto, 1996) & & & $3332 \pm 4$ & & 3.3 \\
\hline Serra do Eixo granitoid (Santos Pinto, 1996) & & & $3158 \pm 5$ & & 3.3 \\
\hline Mariana granitoid (Santos Pinto, 1996) & & & $3259 \pm 5$ & & 3.5 \\
\hline Piripá gneisses (Bastos Leal, 1998) & & & & $3200 \pm 11^{*}$ & 3.5 \\
\hline Malhada de Pedra granite (Santos Pinto, 1996) & $2840 \pm 34$ & & & & 3.3 \\
\hline Pé de Serra granite (Marinho, 1991) & $2560 \pm 110$ & & & & 3.1 \\
\hline
\end{tabular}

Ages of the main Archean plutonic and supracrustal rocks by different radiometric methods. The asterisk indicate SHRIMP data; WR: whole rock. 
(a)

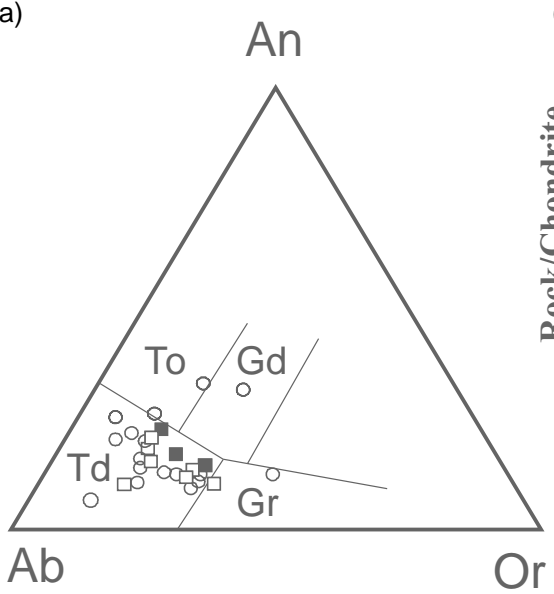

(b)

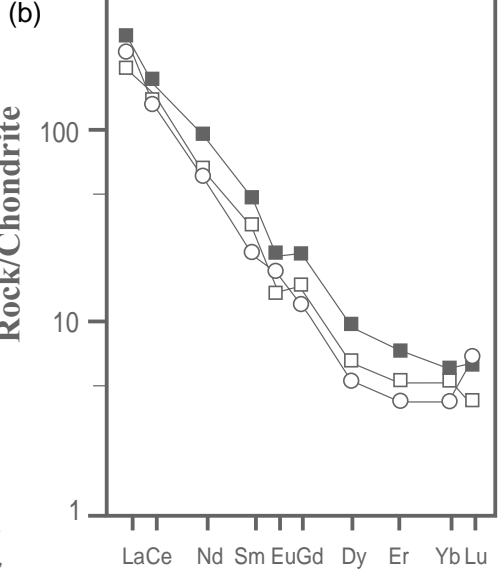

Fig. 5. Gavião block: representative analyses of 3.4-3.3 and 3.2-3.1 Ga TTGs in the An-Ab-Or diagram (Barker and Arth, 1976). Chondrite-normalized REE patterns typically have LREE enrichment and HREE depletion. See text for discussion. To, tonalite; Td, trondhjemite; Gd, granodiorite and Gr, granite.

1998; Peucat et al., 2002). In the Contendas-Mirante belt, for example, komatiites, pyroclastic rocks and exhalative chemical sediments overly early continental tholeiitic basalts with $\mathrm{Nd} T_{\mathrm{DM}}$ model ages of $3.3 \mathrm{Ga}$ and a $\mathrm{Pb}-\mathrm{Pb}$ whole rock isochron age of about $3.0 \mathrm{Ga}$ (Fig. 6; Table 2). Banded iron formation in the chemical sediment unit has a $\mathrm{Pb}-\mathrm{Pb}$ whole rock isochron age of $3265 \pm 21 \mathrm{Ma}$ and a $3.3 \mathrm{Ga} \mathrm{Nd} T_{\mathrm{DM}}$ model age
(Table 2). Pillowed tholeiitic basalts and sub-volcanic rocks have ages of $3011 \pm 159 \mathrm{Ma}(\mathrm{Pb}-\mathrm{Pb}$ whole rock isochron), $3304 \pm 31 \mathrm{Ma}$ (U-Pb zircon) and $3.3 \mathrm{Ga}$ (Nd $T_{\mathrm{DM}}$ model; Table 2 ). These basic volcanic rocks nark the occurrence of mantle-derived magmatism which followed the consolidation of the TTG continental segment. In the northern part of the Gavião block, similar volcanic rocks were found in the

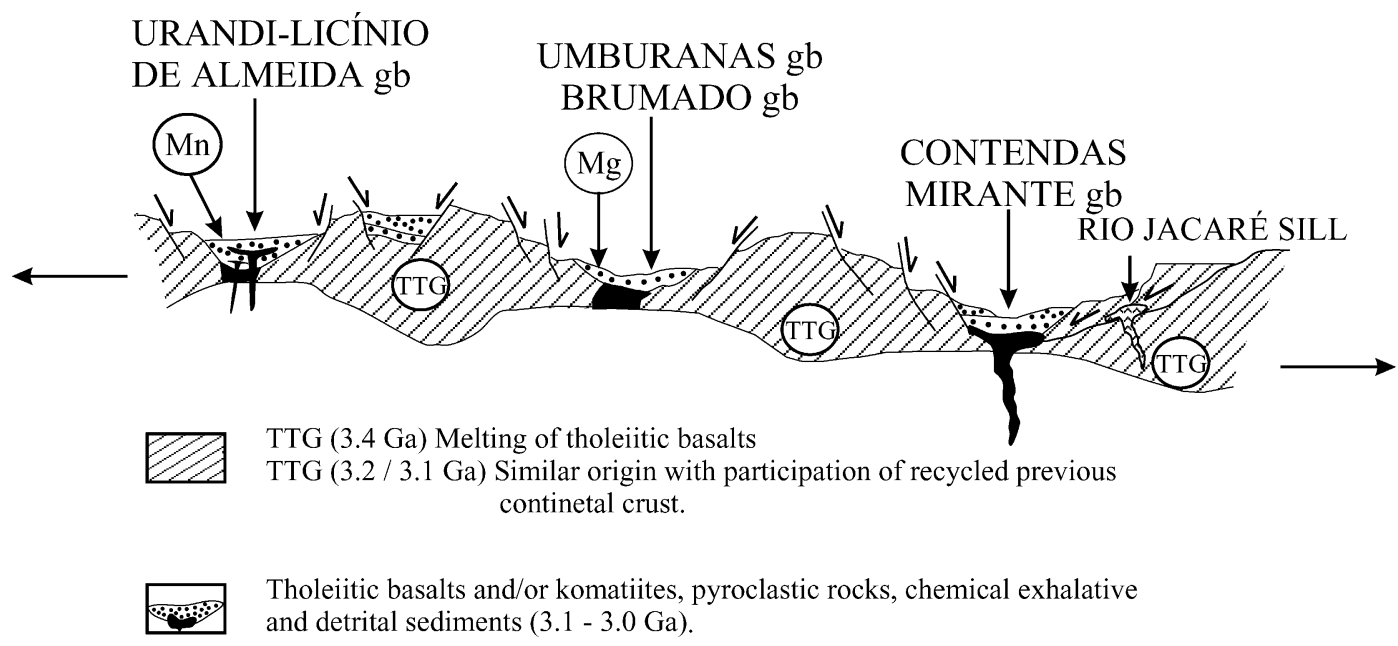

Fig. 6. Gavião block. Geological cross-section showing 3.1-3.0 Ga intracratonic basins which evolved to greenstone belts, some of which contain important manganese (Urandi-Licínio de Almeida greenstone belt) and magnesite deposits (Brumado greenstone belts). 
Table 2

Gavião block

\begin{tabular}{|c|c|c|c|c|c|}
\hline Local & $\begin{array}{l}\mathrm{Rb}-\mathrm{Sr} \\
(\mathrm{Ma})\end{array}$ & $\begin{array}{l}\mathrm{Pb}-\mathrm{Pb} \text { WR } \\
(\mathrm{Ma})\end{array}$ & $\begin{array}{l}\mathrm{Pb}-\mathrm{Pb} \text { single } \\
\text { zircon }(\mathrm{Ma})\end{array}$ & $\begin{array}{l}\text { U-Pb zircon } \\
(\mathrm{Ma})\end{array}$ & $\begin{array}{l}T_{\mathrm{DM}} \\
(\mathrm{Ga}) \\
\end{array}$ \\
\hline Contendas acid sub-volcanic (Marinho, 1991) & & $3011 \pm 159$ & & $3304 \pm 31$ & 3.3 \\
\hline Jurema-Travessão tholeiites (Marinho, 1991) & & $3010 \pm 160$ & & & 3.3 \\
\hline BIF (Marinho, 1991) & & $3265 \pm 21$ & & & 3.3 \\
\hline Calc-alkaline volcanic (Marinho, 1991) & & $2519 \pm 16$ & & & 3.4 \\
\hline Jacaré sill (Marinho, 1991) & & $2474 \pm 72$ & & & 3.3 \\
\hline Umburanas detritic sediments (Bastos Leal, 1998) & & & & $\begin{array}{l}3335 \pm 24^{*} \\
3040 \pm 24^{*}\end{array}$ & \\
\hline Guajeru detritic sediments (Bastos Leal, 1998) & & & $\begin{array}{l}2861 \pm 3 \\
2664 \pm 12\end{array}$ & & \\
\hline Mundo Novo metadacite (Peucat et al., 2002) & & & $3250 \pm 7$ & $3305 \pm 9^{*}$ & 3.3 \\
\hline
\end{tabular}

Ages of the main supracrustal rocks in the Archean greenstone belts, using the common dating methods. Ages with asterisk by SHRIMP.

Mundo Novo greenstone belt. Here, metadacite has been dated (Peucat et al., 2002) at $3250 \pm 7 \mathrm{Ma}$ $(\mathrm{Pb}-\mathrm{Pb}$ single zircon), $3305 \pm 9 \mathrm{Ma}(\mathrm{U}-\mathrm{Pb}$ zircon) and $3.38 \mathrm{Ga}\left(\mathrm{Nd} T_{\mathrm{DM}}\right.$ model age).

Detailed $\mathrm{U}-\mathrm{Pb}$ zircon and $\mathrm{Pb}-\mathrm{Pb}$ single zircon ages from detrital rocks (Bastos Leal, 1998) demonstrate the presence of two zircon populations with ages of $3.33-3.04 \mathrm{Ga}$ in the Umburanas belt, and $2.8-2.6 \mathrm{Ga}$ in the Guajeru belt (Table 2). The wide age spectra obtained are compatible with the long crustal evolution found for the Gavião block, and imply that the detritial sequences were derived by erosion of distinct pre-existing continental rocks (Teixeira et al., 2000).

The ores related to the Archean greenstone belts are important manganese and magnesite deposits, both of volcano-sedimentary origin (Fig. 7). The manganese deposits of the Urandi-Licínio de Almeida belt (one of the less well-known belts) consist of layers $0.5-3 \mathrm{~m}$ thick associated with jaspilite, banded iron formation, dolomite and basic rocks, interfolded by regional deformation. The ore consists of metamorphic oxide minerals with manganese in lower oxidation states, such as jacobsite and hausmanite, besides manganese carbonate and silicate. It also contains supergene oxides with more oxidised manganese (Ribeiro Filho, 1968; Machado, 1977). The huge magnesite deposits of the Brumado belt, regarded as the largest in South America, are in the form of thick beds associated with metadolomite, calc-silicate rocks, quartzite, banded iron formation, metabasites and metaultrabasites. The magnesium source is believed to have been formed by volcano-exhalative processes in calm water en- vironments. The large talc reserves associated with the magnesite deposits may have been formed during ensuing hydrothermal episodes involving silica-rich fluids which transformed the magnesite into talc (Schobbenhaus and Coelho, 1986). In the Mundo Novo greenstone belt, important indications of $\mathrm{Cu}, \mathrm{Pb}$ and $\mathrm{Zn}$ volcano-sedimentary sulfide mineralization associated to the $3.2 \mathrm{Ga}$ metadacites were recently found.

The amphibolite facies tonalite-trondhjemite-granodiorite association in the central part of the Gavião block was dated at 3.03-2.84 Ga by $\mathrm{Rb}-\mathrm{Sr}$ whole rock

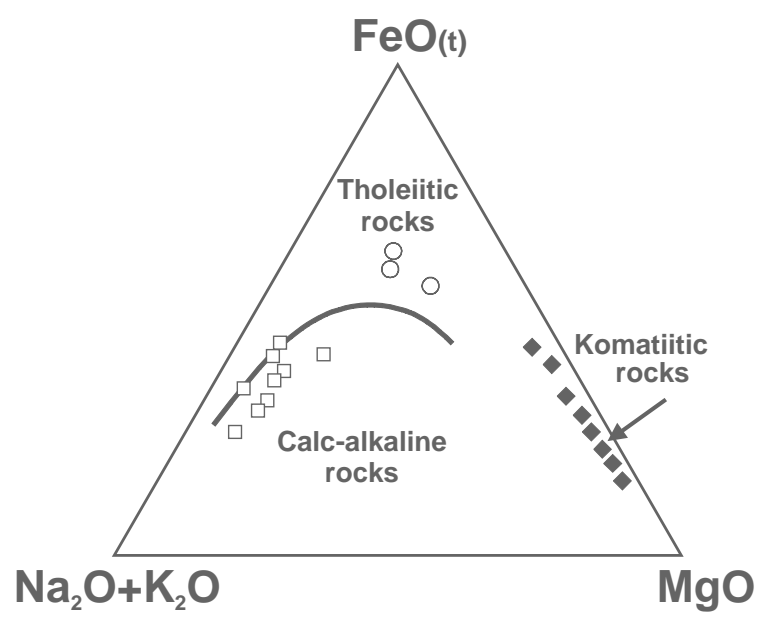

Fig. 7. Gavião block. AFM diagram for komatiitic, tholeiitic and calc-alkaline volcanic rocks from the Umburanas greenstone belt. Division proposed by Irvine and Baragar (1971). 
isochron and $\mathrm{Pb}-\mathrm{Pb}$ single zircon grain methods, and was shown to be the product of partial melting of the earlier TTG gneisses (Santos Pinto, 1996). In addition, high-K calc-alkaline (Bastos Leal et al., 1996) and peraluminous (Marinho, 1991; Marinho et al., 1994a) granites were emplaced at about 2.9-2.8 Ga. Clear evidence for petrogenesis by partial melting of earlier continental crust was found, which implies that orogenic processes operated during the Archean.

Possibly Archean structures can be distinguished in the $3.4 \mathrm{Ga}$ grey gneisses which occur as a giant mega-enclave in the younger grey gneisses, and which preserve a foliation distinct from that of the host rocks (Teixeira et al., 2000). The host rocks have planar and linear magmatic preferred orientations, marked by undeformed plagioclase phenocrysts and biotite grains, which were only slightly folded during the Paleoproterozoic and/or Transamazonian shortening episodes. The flat preferred orientations resulted from the action of horizontal kinematics during the early emplacement of the younger grey gneisses. Close to the Umburanas greenstone belt, the $3.2 \mathrm{Ga}$ grey gneisses display a flat foliation with sheath folds attributed to Archean deformation (Sabaté et al., 1988). In view of the great thickness of the $3.2 \mathrm{Ga}$ Arcean crust (Martin et al., 1997), as well as the intense migmatization and the well-developed Archean foliation of the grey gne- sisses, this terrains are interpreted to be the product of crustal thickening (Teixeira et al., 2000), favouring the idea that modern-style plate tectonics operated in the Gavião block during the Archean.

\section{The Jequié block}

The Jequie block is in tectonic contact with the Gavião block (Fig. 2). It comprises rocks which were in the amphibolite facies prior to the Paleoproterozoic collision: (i) heterogeneous migmatites with inclusions of supracrustal rocks, which correspond to the older component of the block, dated at $2900 \pm 24 \mathrm{Ma}$ by $\mathrm{Rb}-\mathrm{Sr}$ whole rock isochron, and with $\mathrm{Nd} T_{\mathrm{DM}}$ model ages of $2.9 \mathrm{Ga}$ in the migmatites, and $3.3 \mathrm{Ga}$ in basic enclaves (Wilson, 1987; Marinho et al., 1994a); and (ii) the younger component of granodiorite and granite intrusions with $\mathrm{U}-\mathrm{Pb}$ zircon ages of approximately $2.8-2.6 \mathrm{Ga}$, and $\mathrm{Nd} T_{\mathrm{DM}}$ model ages of $3.0 \mathrm{Ga}$ (Wilson, 1987; Alibert and Barbosa, 1992). The supracrustal rocks are believed to be intracratonic basin deposits, and are composed of basalt, andesitic basalt, quartz-felspathic bands intercalated with chert or quartzite, kinzigite, graphitite, banded iron formation, and mafic-ultramafic rocks (Fig. 8). Some graphitites and banded iron formations form small

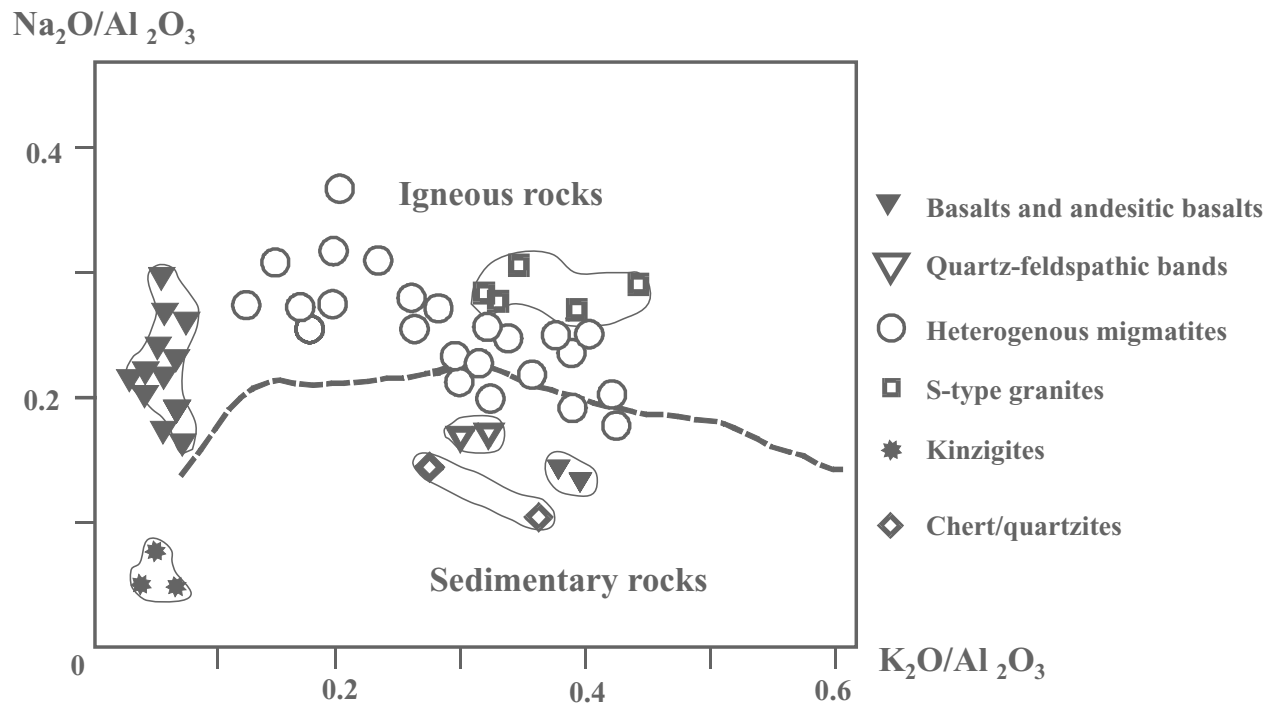

Fig. 8. Jequié block: diagram after Garrels and Mackenzie (1971) showing the great variety of rocks in the older component of the block. 


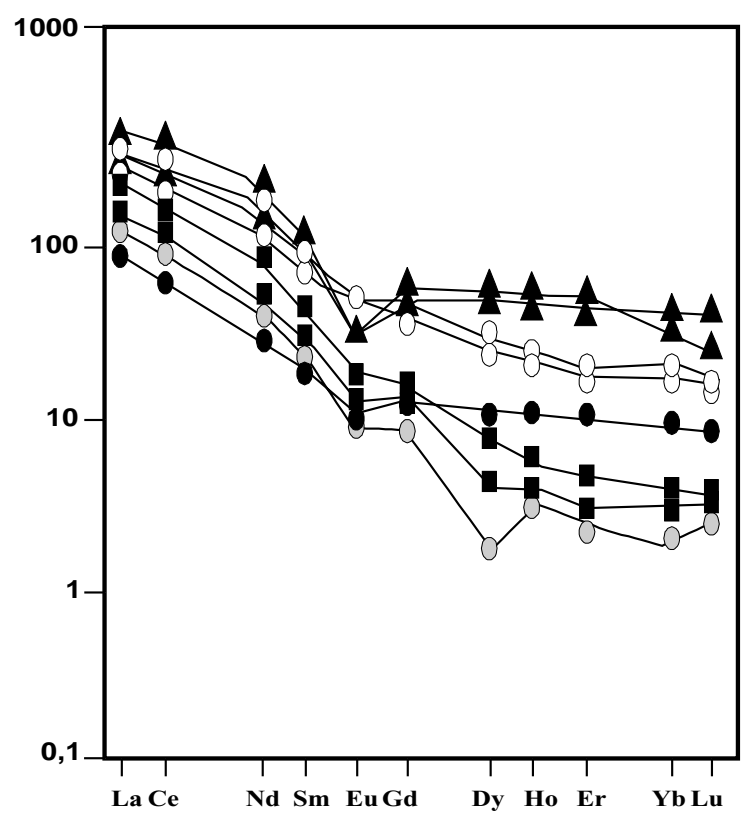

Fig. 9. Jequié block: chondrite normalized by Evensen et al. (1978). REE patterns which illustrate the variety of intrusive rocks in the younger component.

ecopnomic deposits, and nickel mineralizations have been identified in dunite and peridotite sills which are apparently concordant with the other supracrustal rock. The younger component (Fig. 9) is formed by multiple calc-alkaline intrusions including (i) the high-Ti Mutuipe granite (Fornari, 1992) with a U-Pb zircon age of $2689 \pm 1 \mathrm{Ma}$;(ii) the $2810 \pm 3 \mathrm{Ma}$, low-Ti Laje granite (Fornari, 1992; Alibert and Barbosa, 1992); (iii) the Valentim granite with a single zircon $\mathrm{Pb}-\mathrm{Pb}$ evaporation age of $2631 \pm 18 \mathrm{Ma}$; and (iv) the Maracás granite with a $\mathrm{Rb}-\mathrm{Sr}$ whole rock isochron age of $2800 \pm 12 \mathrm{Ma}$ and a $2660 \pm 70 \mathrm{Ma} \mathrm{Pb}-\mathrm{Pb}$ whole rock isochron age (Table 3 ). These rocks sometimes contain enclaves of the older supracrustal rocks (Fig. 8). So far, no geochemical signs of recycling of older TTG crust have been found in the Jequié block, and typical TTG suites are absent.

The rocks of the Jequié block were intensely deformed during the Paleoproterozoic Transamazonian Cycle, discussed further on. Although the episodes during this cycle clearly influenced the architecture of the block, the presence of older structures has been postulated (e.g., Barbosa, 1986; Marinho et al., 1994b; Ledru et al., 1994), although the existence of earlier metamorphism is a matter of debate.

In the Jequie block, Fe-Ti-V mineralizations are hosted in small gabbro-anorthosite bodies, such as that of Rio Piau. Based on field evidence, such as the presence of chilled margins, these bodies are regarded as having intruded the Jequié block plutonic rocks. Major elements and REE also suggest that they are geochemically distinct from the other plutonic rocks, having a tholeiitic character (Barbosa, 1986; Barbosa and Fonteilles, 1989). Although more recent work indicates a Paleoproterozoic age for these rocks, in earlier literature they are treated as Archean (Cruz, 1989). These bodies penetrated deep-seated NNE-SSW trending shear zones (Cruz and Sabaté, 1995; Cruz et al., 1999), and are surrounded by a irregular narrow zone enriched in $\mathrm{Fe}-\mathrm{Ti}-\mathrm{V}$ oxides (magnetite, ilmenite, maghemite and hematite). Genetically these $\mathrm{Fe}-\mathrm{Ti}-\mathrm{V}$-rich rocks are regarded as the end product of fractional crystallization and magmatic accumulation, settling from basic tholeiitic magma where changes in oxygen fugacity favoured the iron-titanium concentration (Cruz and Lima, 1998).

Table 3

Jequié block

\begin{tabular}{|c|c|c|c|c|}
\hline Local & $\mathrm{Rb}-\mathrm{Sr}(\mathrm{Ma})$ & $\mathrm{Pb}-\mathrm{Pb} \mathrm{WR}(\mathrm{Ma})$ & $\mathrm{U}-\mathrm{Pb}$ zircon $(\mathrm{Ma})$ & $T_{\mathrm{DM}}(\mathrm{Ga})$ \\
\hline Ubaíra basic Enclaves (Wilson, 1987; Marinho et al., 1994a,b) & & & & 3.3 \\
\hline Ubaíra migmatites (Wilson, 1987; Marinho et al., 1994a,b) & $2900 \pm 24$ & & & 3.2 \\
\hline Jequié migmatite (Wilson, 1987; Marinho et al., 1994a,b) & & & & 2.9 \\
\hline Maracás granite (Alibert and Barbosa, 1992) & $2800 \pm 12$ & $2660 \pm 70$ & & 3.2 \\
\hline Mutuípe granodiorite (Alibert and Barbosa, 1992) & & & $2810 \pm 3$ & 3.0 \\
\hline Laje granodiorite (Alibert and Barbosa, 1992) & & & $2689 \pm 1^{*}$ & 3.0 \\
\hline
\end{tabular}

Ages of the main Archean plutonic rocks according to different radiometric methods. Other references as in Table 1. The asterisk represent SHRIMP data; WR: whole rock. 
Table 4

Serrinha block

\begin{tabular}{lllll}
\hline Local & $\begin{array}{l}\mathrm{Rb}-\mathrm{Sr} \\
(\mathrm{Ma})\end{array}$ & $\begin{array}{l}\mathrm{Pb}-\mathrm{Pb} \\
\text { single } \\
\text { zircon }(\mathrm{Ma})\end{array}$ & $\begin{array}{l}\mathrm{U}-\mathrm{Pb} \\
\text { zircon } \\
(\mathrm{Ma})\end{array}$ & $\begin{array}{l}T_{\mathrm{DM}} \\
(\mathrm{Ga})\end{array}$ \\
\hline $\begin{array}{l}\text { Serrinha porphiritic } \\
\text { orthogneiss (Rios, }\end{array}$ & & & 3055.15 & 3.12 \\
2002) & & & 3078.98 & 3.17 \\
& & 2807.04 & \\
Rio Capim tonalite & 3120 & 3000 & 3095.94 & \\
$\quad$ (Oliveira et al., & & 2900 & & \\
1999) & & 2650 & & \\
\hline
\end{tabular}

Ages of the main Archean plutonic rocks using different radiometric methods; WR: whole rock.

\section{The Serrinha block}

This is an elongated $\mathrm{N}-\mathrm{S}$ crustal segment up to $250 \mathrm{~km}$ long and $70 \mathrm{~km}$ at its widest part. It is limited to the east by the Mesozoic-Cenozoic rift basin and to the west and south by the Itabuna-Salvador-Curaçá belt through tectonic contacts (Figs. 2 and 3). It does not possess any visible connection with either the Jequié block or the Gavião block, although it has some lithologic similarities with the latter. It is composed of medium-grade gneiss-migmatitic rocks, with porphyritic orthogneiss (2807-3095 Ma, by U-Pb on zircon; Rios, 2002; Table 4) and tonalites (3120 and $3000-2650 \mathrm{Ma}$, by $\mathrm{Rb}-\mathrm{Sr}$ and $\mathrm{Pb}-\mathrm{Pb}$ single zircon methods, respectively, Oliveira et al., 1999; Table 4). Recent $\mathrm{U}-\mathrm{Pb}$ determinations on zircon from tonalitic gneisses of the northern part of the Serrinha block gave ages between 3.13 and $3.05 \mathrm{Ga}$ (Cordani et al., 1999). These rocks constitute the basement for the Rio Itapicuru and Capim Paleoproterozoic greenstone belts, described further on.

\section{The Itabuna-Salvador-Curaçá belt}

The Itabuna-Salvador-Curaçá belt constitutes a wide, essentially magmatic belt that borders the Archean continental segment of the Jequié block at the east and north. Metamorphic grade is in the granulite facies under conditons of $5-7 \mathrm{kbar}$ and $850^{\circ} \mathrm{C}$ (Barbosa, 1990).

With the exception of Paleoproterozoic tonalites/ trondhjemites (TT6), the southern part of the
Table 5

Itabuna-Salvador-Curaçá belt

\begin{tabular}{llll}
\hline Local & $\begin{array}{l}\mathrm{Pb}-\mathrm{Pb} \text { single } \\
\text { zircon (Ma) }\end{array}$ & $\begin{array}{l}\mathrm{U}-\mathrm{Pb} \text { zircon } \\
(\mathrm{Ma})\end{array}$ & $\begin{array}{l}T_{\mathrm{DM}} \\
(\mathrm{Ga})\end{array}$ \\
\hline $\begin{array}{l}\text { Ipiaú tonalite } \\
\quad \text { (Ledru et al., 1994) }\end{array}$ & $2634 \pm 7$ & & \\
$\begin{array}{c}\text { Caraíba TTG } \\
\quad \text { Silva et al., 1997) }\end{array}$ & & $2695 \pm 12^{*}$ & 3.4 \\
$\begin{array}{c}\text { Caraíba chanockite } \\
\quad(\text { Silva et al., 1997) }\end{array}$ & & $2634 \pm 19^{*}$ & 3.4 \\
$\begin{array}{c}\text { Ipiaú monzonite } \\
\quad \text { (Ledru et al., 1994) }\end{array}$ & $2450 \pm 1$ & & 2.4 \\
\hline
\end{tabular}

Ages of the main Archean plutonic rocks by different radiometric methods. The Asterisk represent SHRIMP data; WR: whole rock.

Itabuna-Salvador-Curaçá belt (Figs. 2 and 3) is composed of at least three tonalite/dacite or trondhjemite/rhyolite groups with approximate single zircon $\mathrm{Pb}-\mathrm{Pb}$ evaporation ages of $2.6 \mathrm{Ga}$ (TT1, TT2, TT5, Fig. 10; Barbosa et al., 2000c; Table 5). The TT5 Ipiau tonalite with an age of $2634 \pm 7 \mathrm{Ma}$ (Table 5) is an example. Analysis of their REE geochemistry shows that these tonalites/trondhjemites, with low-K calc-alkaline signatures, are interpreted to be the products of partial melting of tholeiitic oceanic crust (Fig. 11). Monzonite with shoshonitic affinity (Fig. 12) dated at about $2.4 \mathrm{Ga}(\mathrm{Pb}-\mathrm{Pb}$ evaporation on zircon; Ledru et al., 1994) and $2.4 \mathrm{Ga}$ $\left(\mathrm{Sm} / \mathrm{Nd}, T_{\mathrm{DM}}\right.$; Table 5$)$ occurs in this belt as expressive intrusive bodies. From east to west, therefore, arc tholeiitic rocks are succeeded by shoshonites. With the chemical characteristics and the interpreted tectonic setting, the southern part of this belt resembles modern volcanic arc or active continental margin magmatic associations (Figueirêdo, 1989; Barbosa, 1990). Island arcs, back-arc basins and subduction zones were therefore the predominant environments during the original construction of this belt (Barbosa, 1997; Barbosa and Sabaté, 2000, 2002; Fig. 13).

Deposition of supracrustal rocks occurred in these environments, probably during Archean time. Cherts, pelites, banded iron formation, calc-silicate rocks, manganesiferous sediments containing baryte, are all associated with ocean floor basalts (Fig. 11). The two latter types, which underwent deformation under high metamorphic grade, as discussed further on, are presently the site for dozens of small mines which have been operated sporasdically (Toniatti and Barbosa, 1973). In the manganese deposits, the primary beds are 


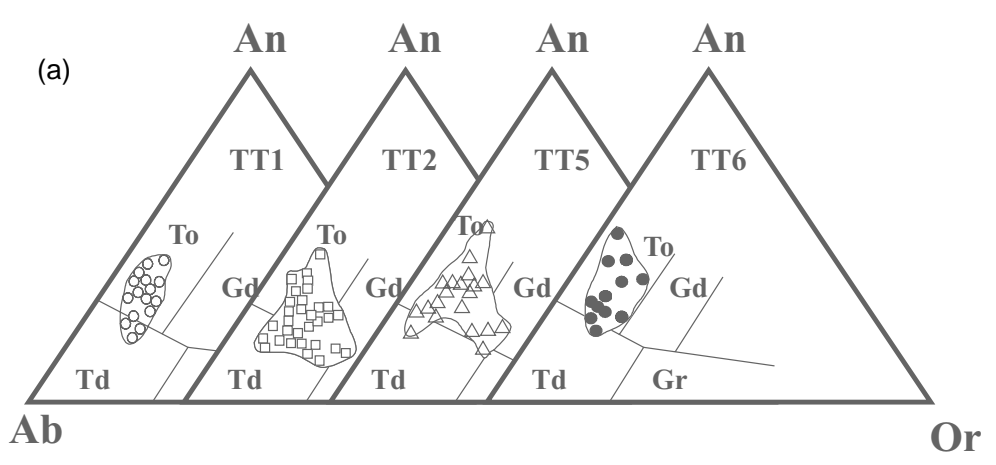

(b)

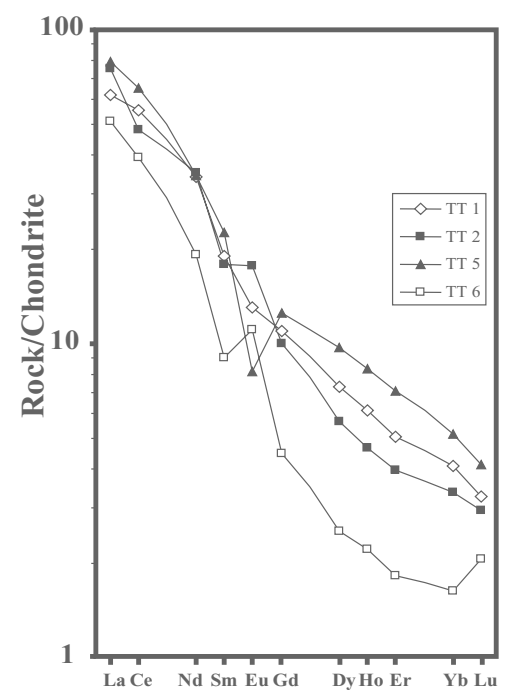

Fig. 10. Southern Itabuna-Salvador-Curaça belt: (a) Barker and Arth's (1976) diagram identifies the four families of granulitized TTGs, of which TT1, TT2 and TT5 are Archean, and TT6 is Paleoproterozoic and (b) average representative REE patterns for the four TTG suites.
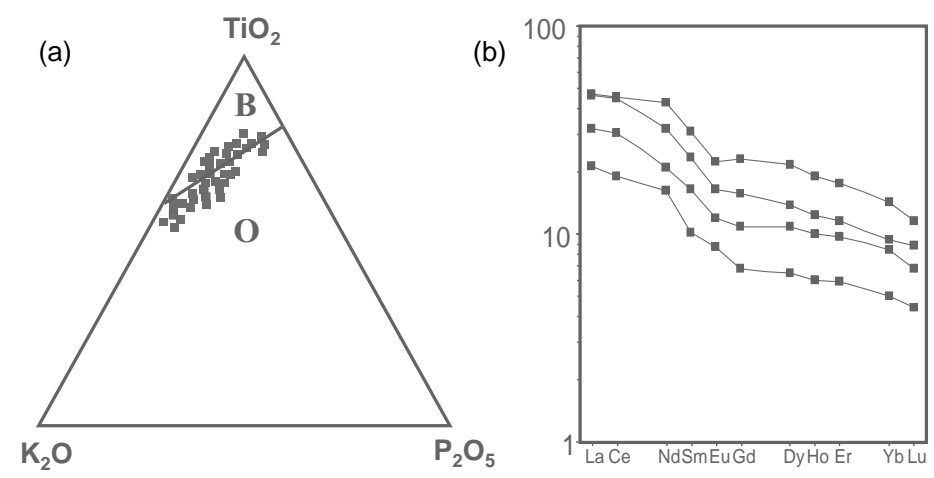

Fig. 11. Southern Itabuna-Salvador-Curaçá belt: (a) triangular diagram after Pearce et al. (1975): field B = ocean floor basalts, O = other basalts and (b) REE patterns for gabbros and/or basalts associated with granulitized supracrustal rocks which occur as enclaves in the TT suites. 

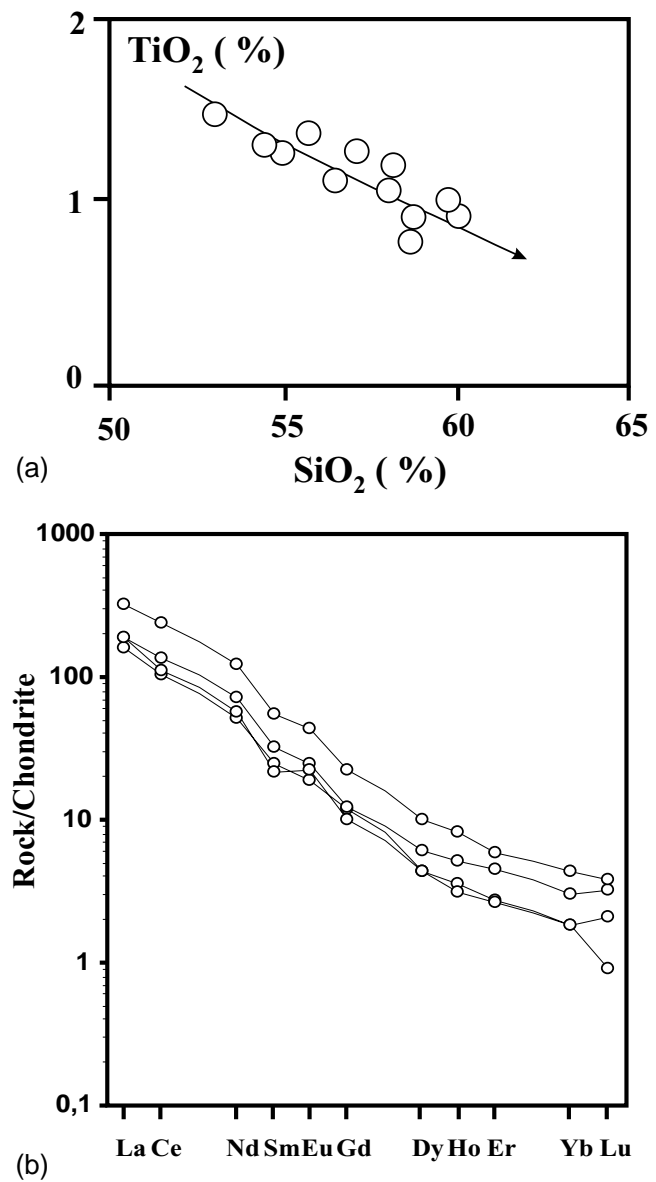

Fig. 12. Southern Itabuna-Salvador-Curaçá belt: (a) well-defined trends for monzonites in the $\mathrm{TiO}_{2}$ vs. $\mathrm{SiO}_{2}$ diagram; and (b) REE patterns indicating the shoshonitic affinities of the mozonites.

composed of pyroxmangite, rhodonite, plagioclase, quartz, spessartite, allabandite and graphite while the supergenic ore consists of pyrolusite, psilomelane, cryptomelane and lithiophorite (Valarelli et al., 1982). The type of barite deposit, its association with supracrustal rocks, and isotopic analysis of barite crystals all indicate an origin by volcano-sedimentary processes (Sá and Barbosa, 1990).

The northern part of the Itabuna-Salvador-Curaçá belt (Figs. 2 and 3) consists of an elongated accretionary prism. This part comprises three main lithologic units (Caraiba, São José do Jacuipe and Ipirá complexes), as well as several intrusions. The Caraiba Complex (Figueirêdo, 1981) is made up of metaigneous rocks (Teixeira and Melo, 1990). Trndhjemitic and calc-alkaline orthogneisses are present (Teixeira, 1997). The former are essentially located in continuous bands bordering the belt, and they also occur in its north central part, where they form two parallel, narrow and discontinuous strips produced during the Paleoproterozoic collision discussed further on. The more expressive calc-alkaline rocks occupy the central and eastern part of the belt. Charnockites also crop out in this belt. The distribution of plutonic terrains confers a crude axial symmetry to the belt (Teixeira et al., 2000). The trondhjemitic/tonalitic rocks had a two stage juvenile origin (Martin, 1994; Teixeira, 1997). Silva et al. (1997) dated tonalite and charnockits from the Caraiba Complex by SHRIMP U-Pb analysis of zircon and obtained magmatic crystallization ages of $2695 \pm 12 \mathrm{Ma}$ and $2634 \pm 19 \mathrm{Ma}$, respectively.

The São José do Jacuipe Complex forms discrete bands and lenses tectonically intercalated within the Caraiba Complex near its western border. It is composed of mafic and ultramafic rocks derived from tholeiitic magma and contains a minor crustal contamination component, and represents remnants of old oceanic crust similar to modern ocean floor (Teixeira, 1997), although isotopic data are needed to support this interpretation. The Ipirá Complex also forms narrow strips intercalated within the Caraiba Complex, and consists mainly of garnet-bearing quartzites, $\mathrm{Al}-\mathrm{Mg}$ gneisses with sapphirine, calc-silicate rocks, cherts, banded iron formation, as well as subordinate bands of basic rocks (Teixeira, 1997).

\section{The Paleoproterozoic deformations}

The convergence between Gavião and Jequié blocks is marked by the formation of Jacobina and Contendas-Mirante basins. The latter was installed over the Archean basement formed by the Contendas-Mirante greenstone belt. Similar situation occurred further north, where the Mundo Novo greenstone belt formed part of the substratum of the Jacobina basin.

According to this model, events preceding the collision correspond to: (i) younger calc-alkaline volcanics $(2519 \pm 16 \mathrm{Ma} \mathrm{Pb}-\mathrm{Pb}$ whole rock isochron, and $3.4 \mathrm{Ga} T_{\mathrm{DM}}$ model ages; Table 2); (ii) granite intrusions (Pé de Serra Granite, $2560 \pm 110 \mathrm{Ma} \mathrm{Rb}-\mathrm{Sr}$ whole rock isochron, and $3.1 \mathrm{Ga} T_{\mathrm{DM}}$ model ages; 

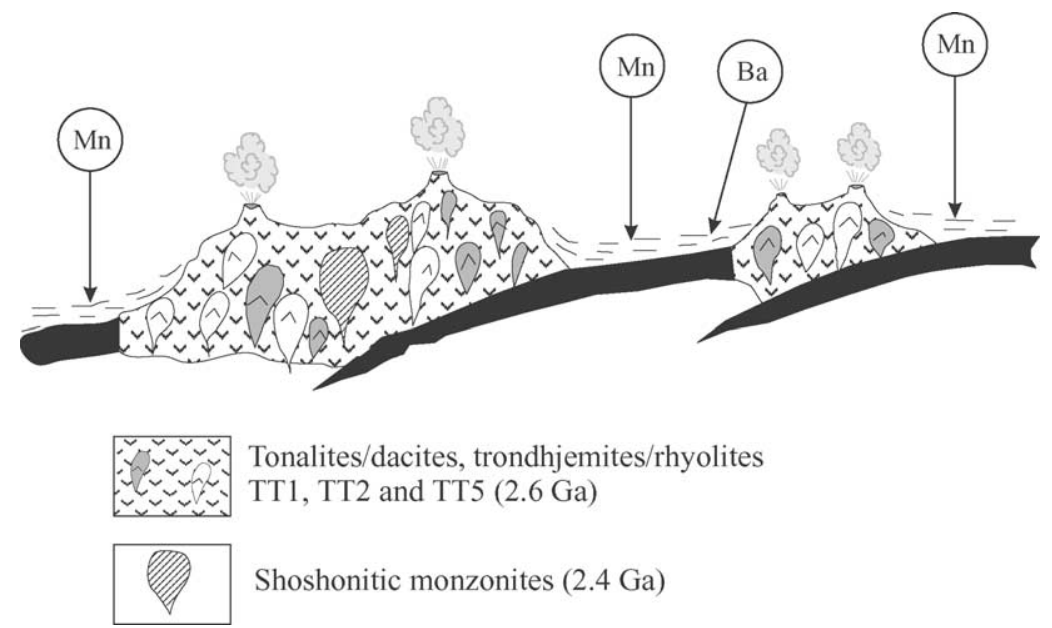

Tonalites/dacites, trondhjemites/rhyolites TT1, TT2 and TT5 $(2.6 \mathrm{Ga})$

Shoshonitic monzonites $(2.4 \mathrm{Ga})$

Fig. 13. Geotectonic model of the Southern Itabuna-Salvador-Curaçá belt with subductionm zones, island arcs and back-arc basins. The probable sites of deposition of volcano-sedimentary manganese and barite deposits are shown.

Table 1) and (iii) mafic ultramafic intrusions (Brito, 1984) (Rio Jacaré Sill, $2474 \pm 72 \mathrm{Ma} \mathrm{Pb} / \mathrm{Pb}$ whole rock isochron, and $3.3 \mathrm{Ga} T_{\mathrm{DM}}$ model ages; Table 2). Phyllites and graywackes are also associated with these Archean greenstone belts, and they are thought to represent rocks laid down during the transition from the Archean to the Paleoproterozoic (Marinho, 1991).

The calc-alkaline volcanic rocks are now composed of foliated metabasalts and metandesites tectonically intercalated in the Contendas-Mirante greenstone belt metapelites, and also occur as a continuous layer flooring the Rio Jacaré tectonic slice. The volcanic rocks therefore constitute the tectonic interface between the slice and the host metasediments of the Contendas-Mirante greenstone belt. As a consequence, the calc-alkaline rocks may represent the volcanic component of magmatism which occurred at about $2.5 \mathrm{Ga}$ near the margin of the Gavião block, proximal and contemporaneous with the deep-seated emplacement of the Rio Jacaré mafic pluton (Teixeira et al., 2000).

The Pé de Serra massif represents a N-S elongated band (ca. $100 \mathrm{~km} \times 5 \mathrm{~km}$ ) interfacing the Jequié block and the supracrustal rocks of the northeastern Contendas-Mirante greenstone belt. It comprises granite with granoblastic textures and mineralogy typical of sub-alkaline rocks, as well as alkaline granite and syenite. The sub-alkaline granite appears strongly deformed and recrystallized by E-W shortening responsible for the foliation and/or local banding and also for tight centimetric to decimetric upright similar folds. The alkaline granite is clearly less deformed and may have been emplaced after the sub-alkaline one. Geochemically, these plutonic rocks have high-K metaluminous compositions with strong REE fractionation and moderate negative Eu anomalies (Teixeira et al., 2000).

The Rio Jacaré sill (Galvão et al., 1981; Fig. 16) is a layered mafic-ultramafic body, with a lower zone composed of gabbro, and a stratified upper zone in which gabbro alternates with pyroxenite (Brito, 1984). $\mathrm{Fe}-\mathrm{Ti}-\mathrm{V}$ deposits are hosted by layered gabbro and pyroxenite. The roughly oval-shaped main body is $400 \mathrm{~m}$ long and $150 \mathrm{~m}$ wide. Vanadiferous magnetite with vanadium oxide content up to $6 \%$ occurs disseminated in pyroxenite or as massive ore layers up to $12 \mathrm{~m}$ thick (Galvão et al., 1981).

Local extensional regimes in the Contendas-Mirante and Jacobina basins favoured the emplacement of the calc-alkaline volcanic rocks, the Pe de Serra massif and the Rio Jacaré sill. The extension is believed to be part of the early stages of continental subduction of the Gavião block underneath the Jequié block. This event caused the build-up of the Contendas-Jacobina collisional belt. Further stages involved the collision of the various crustal segments (Figs. 2 and 14), and the consequent cratonic accretion during the Transamazonian Cycle (ca. 2.3-1.9 Ga) which proba- 


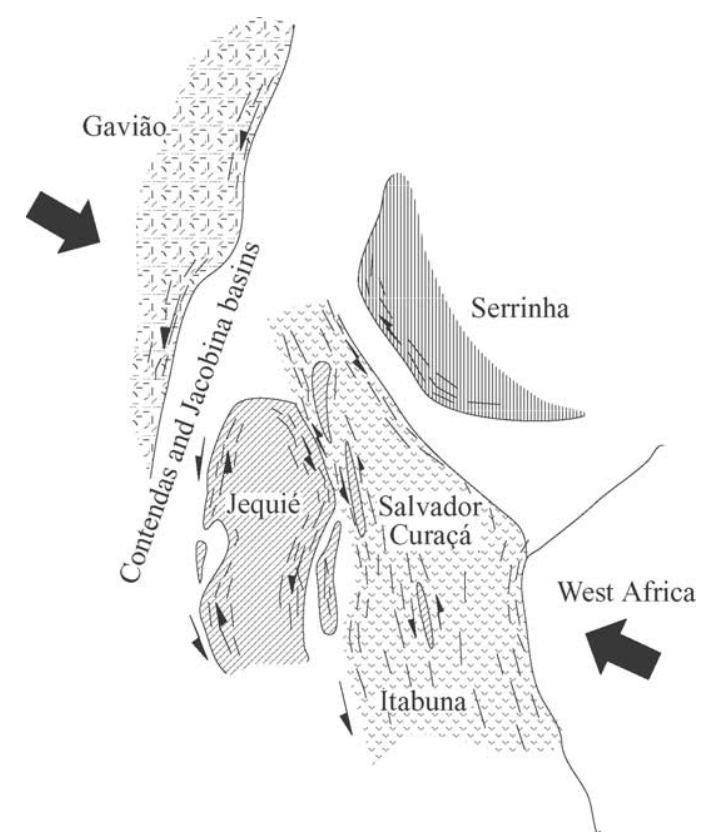

Fig. 14. Relative positions of the Archean blocks prior to the Paleoproterozoic collision, showing the locations of the Paleoproterozoic Contendas and Jacobina basins (Barbosa and Sabaté, 2000, 2002).

bly resulted in the formation of an important mountain range (Figs. 14 and 15). Presently, only remains of the deep roots of these mountains are preserved (Barbosa and Sabaté, 2000, 2002). Evidence for this collision is recorded not only in the structural features but also by the pre-, syn- and post-tectonic Paleoproterozoic rocks present mainly in the Gavião block, Itabuna-Salvador-Curaçá belt and Serrinha block (Table 6). Radiometric age-dating indicates they were formed during the Paleoproterozoic Transamazonian Cycle.

Detrital sediments of the Contendas-Mirante and Jacobina basins were deposited during Paleoproterozoic times at the margin of the Gavião block. Besides the basal Archean greenstone unit, the Contendas-Mirante belt (Fig. 16) contains a distinct Paleoproterozoic unit, composed of two members metamorphosed in greenschist to amphibolite facies: (i) the lower member with a thick flysch sequence and metavolcanic rocks; and (ii) the upper clastic member of graywackes, pelites and argillaceous rocks with conglomerate layers. $\mathrm{Nd} T_{\mathrm{DM}}$ crustal residence

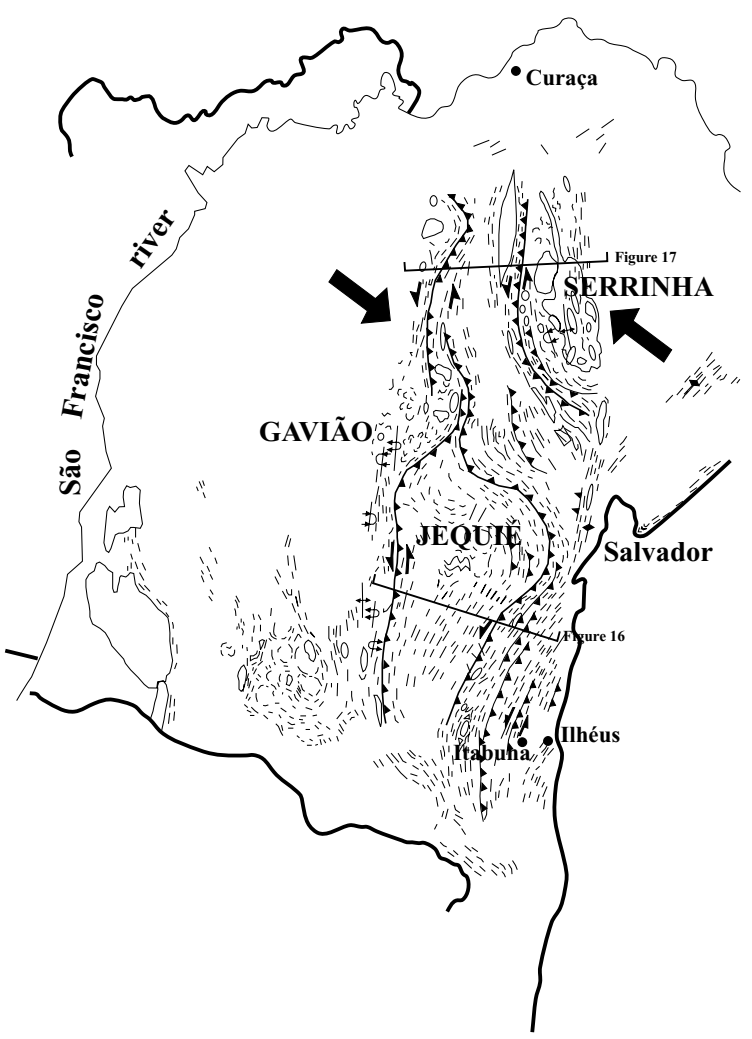

Fig. 15. Positions of the Archean blocks after the Paleoproterozoic Transamazonian Cycle.

ages for the metasediments range between 2.39 and $3.50 \mathrm{Ga}$ (Sato, 1998), showing the participaton of different sediment sources. U-Pb ages on three detrital zircon populations from the Contendas-Mirante upper member are 2.61-2.67 and 2.32-2.38 Ga and $2168 \pm 18 \mathrm{Ma}$, the latter of which corresponds to the maximum deposition age (Nutman and Cordani, 1993; Nutman et al., 1994; Fig. 16; Table 6).

The Jacobina Group detrital deposits (Leo et al., 1964) are similar to the clastic sediments of Contendas-Mirante belt. According to Mascarenhas et al. (1992) and Mascarenhas and Alves da Silva (1994), the Jacobina Group lies in a rift opened in tonalitic-trondhjemitic-granodioritic and migmatite-granitic rocks, over supracrustal rocks of the Mundo Novo greenstone belt, all of them Archean (Fig. 17). The depositional environments of the metamorphic rocks of this rift were fluvio-deltaic and submarine for the upper rocks, and marine for 

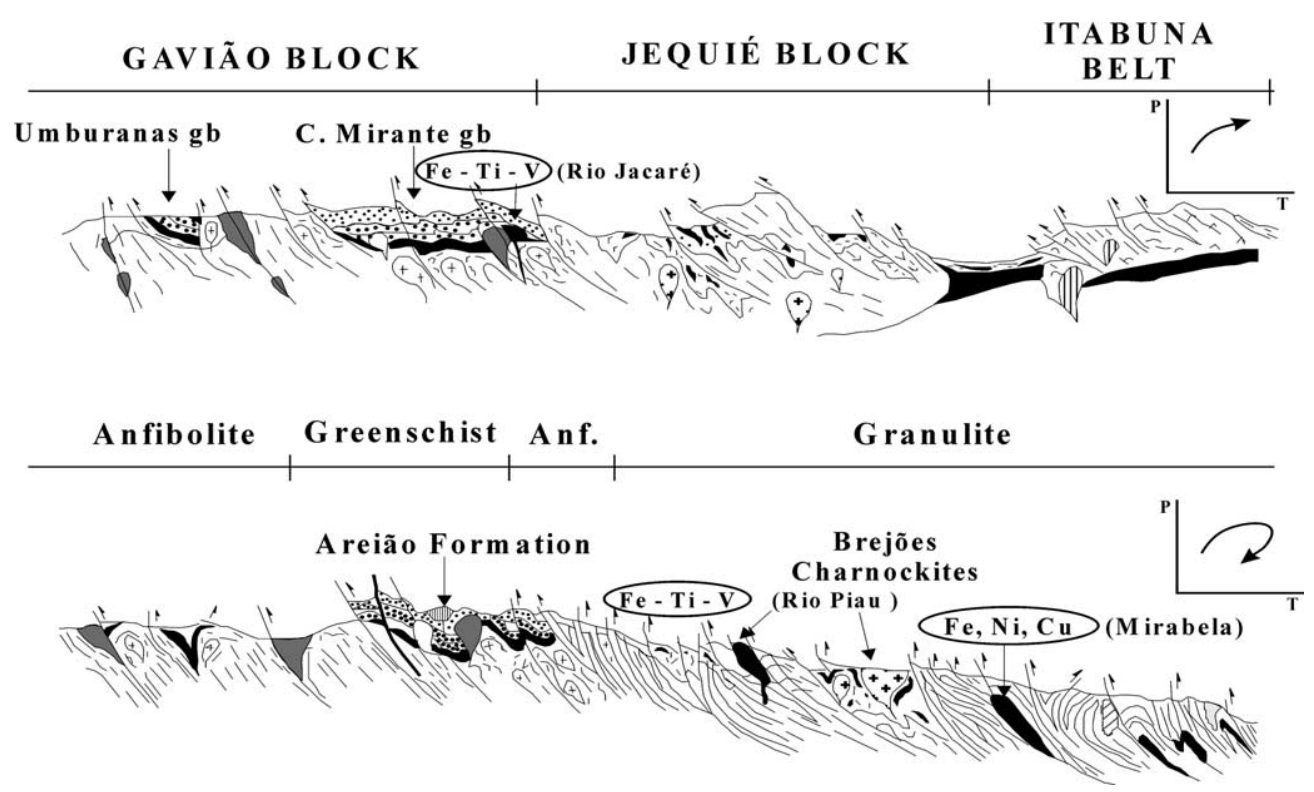

Fig. 16. E-W geotectonic reconstructions of SSE-SSW Bahia, showing the positions of Paleoproterozoic rock units. Upper diagram, earlier phase; lower diagram, present situation. See text for details. Schematic $P-T-t$ paths are shown. The probable sites of deposition of minerals deposits are shown.
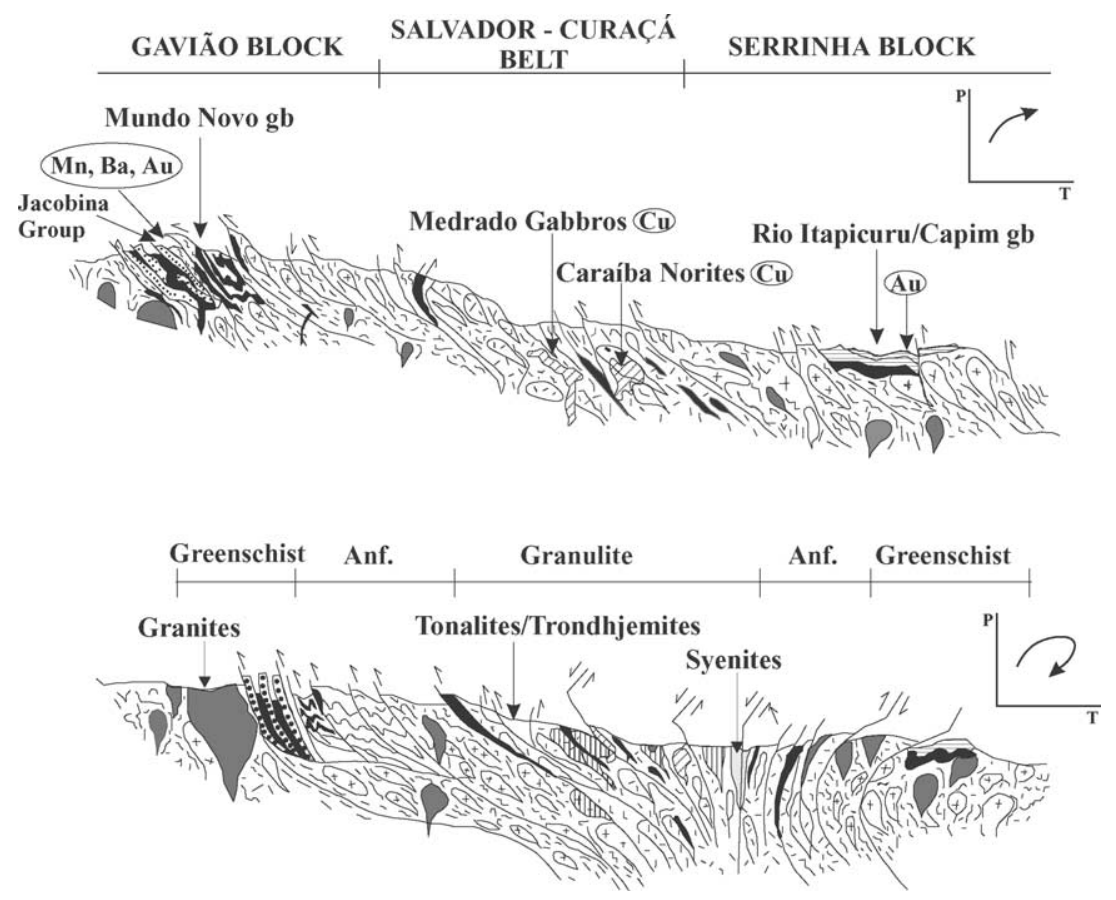

Fig. 17. E-W geotectonic reconstruction for NNE Bahia, with emphasis on the Paleoproterozoic units. Upper diagram, earlier phase; lower diagram, present situation. See text for details. Schematic $P-T-t$ paths are shown. The probable sites of deposition of minerals deposits are shown. 
Table 6

Gavião, Jequié and Serrinha blocks and Itabuna-Salvador-Curaçá belt

\begin{tabular}{|c|c|c|c|c|c|}
\hline Local & $\mathrm{Rb}-\mathrm{Sr}(\mathrm{Ma})$ & $\begin{array}{l}\mathrm{Pb}-\mathrm{Pb} \\
\mathrm{WR}(\mathrm{Ma})\end{array}$ & $\begin{array}{l}\mathrm{Pb}-\mathrm{Pb} \text { single } \\
\text { zircon }(\mathrm{Ma})\end{array}$ & $\begin{array}{l}\mathrm{U}-\mathrm{Pb} \text { zircon } \\
(\mathrm{Ma})\end{array}$ & $T_{\mathrm{DM}}(\mathrm{Ga})$ \\
\hline Caculé granite (Santos Pinto, 1996) & & & $2015 \pm 27$ & & 2.6 \\
\hline Serra da Franga granite (Santos Pinto, 1996) & & & $2039 \pm 11$ & & \\
\hline Umburanas granite (Santos Pinto, 1996) & & & $2049 \pm 5$ & & 3.3 \\
\hline Gameleira granite (Marinho, 1991) & $1947 \pm 57$ & & & & 2.9 \\
\hline Campo Formoso granite (Mougeot, 1996) & $1969 \pm 29$ & & & & 2.6 \\
\hline $\begin{array}{l}\text { Contendas-Mirante detritic sediments } \\
\text { (Nutman et al., 1994) }\end{array}$ & & & & $2168 \pm 18^{*}$ & \\
\hline Jacobina conglomerate (Mougeot, 1996) & & & $\begin{array}{l}3353 \pm 11 \\
2086 \pm 43\end{array}$ & & \\
\hline Itapicuru basic volcanic (Silva, 1992) & & $2209 \pm 60$ & & & 2.2 \\
\hline Itapicuru felsic volcanic (Silva, 1992) & $2080 \pm 90$ & $2109 \pm 80$ & & & 2.1 \\
\hline Ambrósio granite (Rios, 2002) & & & & 2000 & 2.1 \\
\hline Barra do Rocha tonalite (Ledru et al., 1994) & & & $2092 \pm 13$ & & \\
\hline Itabuna tonalite (Barbosa and Sabaté, 2002) & & 2130 & & & 2.6 \\
\hline Pau Brasil tonalite (Correa Gomes, 2000) & & & $2089 \pm 4$ & & \\
\hline Caraíba norite (Oliveira and Lafon, 1995) & & & & 2051 & 2.8 \\
\hline Medrado gabbro (Oliveira and Lafon, 1995) & & & & 2059 & 2.9 \\
\hline Brejões charnockite (Barbosa and Sabaté, 2002) & & & $2026 \pm 4$ & & \\
\hline
\end{tabular}

Ages of the main Paleoproterozoic plutonic and supracrustal rocks by different radiometric methods. The Asterisk represent SHRIMP data; WR: whole rock.

the lower rocks. The upper sub-group includes two detrital formations: (i) the Serra do Corrego conglomeratic and quartzitic formations cut by intrusions of mafic-ultramafic rocks; and (ii) the Rio do Ouro quartzitic formation with intercalations of conglomerates and aluminous schists. The lower sub-group consists of (i) metapelites and quartzites of the Cruz das Almas Formation and (ii) quartzites and phyllites of the Serra da Paciência Formation. Several interpretations for the stratigraphic evolution have been proposed (Leo et al., 1964; Mascarenhas, 1969; Couto et al., 1978; Molinari, 1983; Scarpelli, 1991; Mascarenhas et al., 1992; Mascarenhas and Alves da Silva, 1994). Recently, a new evolution model for the Jacobina Group as a foreland basin deposit has been put forward, associating lithological, structural and metamorphic data (Ledru et al., 1997). Accordingly, the lower member would probably be much older than the upper member. The sedimentation of the Jacobina conglomerates took place in Paleoproterozoic times, as shown by the $\mathrm{Pb}-\mathrm{Pb}$ evaporation ages for the detrital zircons (Mougeot, 1996). One population has an age of $2086 \pm 43 \mathrm{Ma}$, while a second population from the same conglomerates yielded an age of $3353 \pm 11 \mathrm{Ma}$ (Table 6), indicating the participation of Archean sources, probably the grey gneisses of the
Gavião block, in the formation of the basin deposits (Teixeira et al., 2000).

In the Cruz das Almas Formation, which occurs mainly on the eastern side of the Jacobina range, there are numerous manganese deposits associated to metapelites. The ore occurs as lenses and layers of primary oxides, alternating and folded with metapelites, and also as soil crusts and float secondarily enriched in manganese and iron minerals (pyrolusite, psilomelane, limonite, goethite, hematite). The Cruz das Almas Formation also hosts an important barite deposit now being worked. Barite concentrations are associated with quartzites and pelites. Although no detailed study either on the manganese ores or on the barite has been undertaken. their probable origin is believed to be volcano-sedimentary exhalative (Fig. 17). Gold is extracted from the Jacobina gold mines, and comes from pyrite bearing quartz-pebble metaconglomerates and quartzite beds of Serra do Córrego formation (Sims, 1977; Molinari, 1983; Gama, 1982; Molinari and Scarpelli, 1988; Horscroft et al., 1989; Fig. 17). Teixeira et al. (2001) confirm that the two previously recognized mineralized layers of conglomerate are separated by a dominantly quartzite layer. The conglomerate is oligomictic, dominated by rounded, polycrystalline quartz pebbles, with a coarse-grained 
fraction. The sandy matrix is mainly composed of quartz grains, sericite, fuchsite, besides zircon and chromite grains. The quartzite shows granoblastic and blastopsammitic texture, with grain sizes varying from coarse sand to very fine pebble and with minor microcrystals of sericite, fuchsite, andalusite and iron oxide, besides detrital tourmaline, rutile, and zircon. The orebodies (5-6 g Au/t) generally occur at the contact with barren quartzite, accompanied by a network of sulfide veinlets. The gold particles are fibrous or oval-shaped, always attached to pyrite crystals or associated to quartz grains (Mougeot, 1996). Following the evidence of the tectonic study, Ledru et al. (1997) and Milesi et al. (2001) show that the gold mineralization is related to hydrothermal processes that accompany the successive tectonic phases of the collision. Teixeira et al. (2001) also consider that major gold mineralizations are due to hydrothermal processes, but suggest that they are related to Paleoproterozoic retrograde metamorphism (see later). In these cases, the gold mineralizations occur in shear zone-related quartz veins hosted in quartzite of the Rio do Ouro and Cruz das Almas formations (Teixeira et al., 2001).

In the Serrinha block, the Rio Itapicuru and the Rio Capim greenstone belts were formed in back-arc basins (Silva, 1992, 1996; Winge, 1984). In the Rio Itapicuru (Fig. 17): (i) the lower Itapicuru Basic Volcanic unit, dated by the $\mathrm{Pb}-\mathrm{Pb}$ whole rock isochron method at $2209 \pm 60 \mathrm{Ma}$ and with a $T_{\mathrm{DM}}$ model age of $2.2 \mathrm{Ga}$; Table 6) consists of tholeiitic basalts and mafic tuffs, with associated banded iron formation, cherts, and graphitic phyllites; (ii) the intermediate Itapicuru Felsic Volcanic unit is formed mainly by felsic rocks with ages of $2080 \pm 90 \mathrm{Ma}, 2109 \pm 80 \mathrm{Ma}$ and $2.1 \mathrm{Ga}$ obtained by dated by $\mathrm{Rb}-\mathrm{Sr}$ and $\mathrm{Pb}-\mathrm{Pb}$ whole rock isochron, and $\mathrm{Sm}-\mathrm{Nd}$ methods, respectively; Table 6). The calc-alkaline rock compositions range from andesite to dacite; and (iii) the upper unit, composed of thick packages of psefites, psamites and pelites. In the Rio Capim (Fig. 17) felsic volcanic rocks with an age of $2153 \pm 79 \mathrm{Ma}$ obtained by the $\mathrm{Pb}-\mathrm{Pb}$ whole-rock isochron method, also occur together with gabbro and diorite, the latter dated at $2.1 \mathrm{Ga}$ by the U-Pb method on zircons (Oliveira et al., 1999). These Paleoproterozoic greenstone belts are essentially different from the Archean greenstone belts of the Gavião block not only because of their age but mainly because they lack significant komatiitic volcanic rocks (Figs. 16 and 17).
There are important active gold mines in the Rio Itapicuru greenstone belt. Gold occurs in quartz veins, with associated albite, carbonates and sulfides, and is restricted to crustal level greenschist facies shear zones. Mineralized zones are encased in basalt/gabbro and in andesitic lava-pyroclastic rocks, in the southern and central-northern parts of the greenstone belt, respectively. Fluid inclusions from mineralized quartz belong to two major groups: water-carbonic inclusions $\left(\mathrm{H}_{2} \mathrm{O}+\mathrm{CO}_{2}\right)$ and entirely carbonic ones $\left(\mathrm{CO}_{2} \pm \mathrm{CH}_{4} \pm\right.$ $\mathrm{N}_{2}$ ) (Silva et al., 2001). These inclusions, as a rule, yield homogenization values of the order of $2 \mathrm{~kb}$ and $350{ }^{\circ} \mathrm{C}$, compatible with geothermobarometric data, suggesting that devolatilization of the reactions, has occurred during the greenschist facies regional metamorphism, providing fluids that greatly enhanced gold concentration (Silva et al., 2001; Fig. 17).

The Paleoproterozoic collision took place as the crustal segments (Gavião, Jequié and Serrinha) moved along a NW-SE path, identified by the presence of large thrusts and dominantly left-lateral transcurrent zones, as suggested by the kinematics of the late ductile shear zones (Fig. 15).

In northern part of the Itabuna-Salvador-Curaçá belt, the closure of the Serrinha block against the Gavião block promoted significant E-W crustal shortening along an axis identified by a centrifugal vergence of the rock structures (Fig. 17). This shortening produced a "tectonic mélange" with overlapping slices of the Caraiba, São José do Jacuipe and Ipirá complexes, along with $\mathrm{N}-\mathrm{S}$ stretching, compensated by continuous sinistral shear bands, contemporaneous with the successive plutonic emplacements of granites constituting the main framework of the belt. The rheological behaviour varied from viscous magmatic to ductile conditions in the granulitic facies. The two-fold vergence of the resulting framework was evidenced as a "positive flower" tectonic arrangement (Padilha and Melo, 1991) and interpreted as a consequence of an oblique collision between the northern part of the Gavião block and the Serrinha block.

In southern Bahia, during the initial stages of this collision at about $2.4 \mathrm{Ga}$ (Ledru et al., 1994), front ramp tangential tectonics led to obduction of the southern Itabuna-Salvador-Curaçá belt over the Jequié block, and of the latter over the Gavião block (Fig. 16). West-verging recumbent folds are sometimes coaxially refolded in these high-grade metamor- 
phic terrains, exhibiting isoclinal shapes, testifying to the style of ductile deformations. The southern part of Itabuna-Salvador-Curaçá belt, as previously mentioned, has been interpreted as an island-arc related to westward subduction of Archean/Paleoproterozoic oceanic crust, dipping underneath the Jequié block (Figueirêdo, 1989; Barbosa, 1990). The model also postulates the presence of a back-arc basin between the arc and the Jequié continental segment. The rocks formed here would be the supracrustal series now overthrust onto the Jequie block together with the major part of the magmatic belt formed during a possible arc/continent collision (Barbosa, 1990). During the Transamazonian Cycle, strong penetrative granulitic foliation and/or banding affected the country rocks in the Jequié block. The available data lead to the conclusion that the block was affected by at least two episodes of ductile deformation (Barbosa, 1986; Barbosa et al., 1994). According to these authors, the first episode created recumbent folds with approximately $\mathrm{N}-\mathrm{S}$ horizontal axis related to west-verging shear ramps. The first foliation was tightly refolded in an isoclinal style also with a subhorizontal axis but with a subvertical axial plane, sometimes transposing the earlier foliation. Fold interference patterns from these two deformational episodes may occur, at least in cartographic scale (Barbosa, 1986). The available data indicate a model of mega-blocks displaced in depth according to a system of frontal and lateral tectonic ramps (Gomes et al., 1991; Barbosa, 1992).

According to Sabaté and Barbosa in Teixeira et al. (2000), the present-day configuration and the structural framework of Archean Gavião block are also controlled by Transamazonian tectonic events. These tectonics developed in deep ductile, largely penetrative conditions. This is mirrored by the Sete Voltas TTG and Mundo Novo greenstone belt slices that are elongated and imbricated along with Paleoproterozoic supracrustals in the Contendas-Mirante-Jacobina lineament, as well as by the mosaic of outcrops of lithotectonic units, their internal thrust faults and shear zones patterns. The Contendas-Mirante greenstone belt appears as a large $\mathrm{N}-\mathrm{S}$ structure which branches into smaller belts at its northern and southern extremities (Marinho and Sabaté, 1982). Internally, the synform presents a succession of imbricated second order antiforms complicated by thrust and shear surfaces. The most prominent feature is the interference of two main co-axial folding episodes related to coeval shear structures. In fact, the continuous deformation resulted from an E-W shortening which pinches the belt between the underthrusted Gavião block and the overthrusted Jequié block (Fig. 16).

In different parts of the Gavião block, several granite bodies were emplaced during the Paleoproterozoic deformation of the Transamazonian Cycle. They present magmatic preferred orientations and superposed ductile coaxial deformations. Some examples are (Table 6): (i) the Caculé Granite (2015 $\pm 27 \mathrm{Ma}$ and $2.6 \mathrm{Ga}$, dated by the $\mathrm{Pb}-\mathrm{Pb}$ single zircon evaporation and $\mathrm{Sm}-\mathrm{Nd} T_{\mathrm{DM}}$ methods, respectively); (ii) the Serra da Franga Granite (2039 $\pm 11 \mathrm{Ma}$ by the $\mathrm{Pb}-\mathrm{Pb}$ single zircon evaporation method); (iii) the Umburanas Granite ( $2049 \pm 5 \mathrm{Ma}$ and $3.3 \mathrm{Ga}$ dated by the $\mathrm{Pb}-\mathrm{Pb}$ single zircon evaporation and $\mathrm{Sm}-\mathrm{Nd} T_{\mathrm{DM}}$ methods, respectively) and, (iv) the Gameleira Granite $(1947 \pm 57 \mathrm{Ma}$ and $2.9 \mathrm{Ga}$, dated by $\mathrm{Rb}-\mathrm{Sr}$ and $\mathrm{Sm}-\mathrm{Nd} T_{\mathrm{DM}}$ methods, respectively).

In the northern part of the Itabuna-Salvador-Curaçá belt (Figs. 2 and 3), single zircon $\mathrm{Pb}-\mathrm{Pb}$ determinations on magmatic idiomorphic zircon nuclei from the Caraiba orthogneiss and their metamorphic overgrowths yielded similar ages of approximately $2.1 \mathrm{Ga}$ (Sabaté et al., 1994) which may therefore correspond to the intrusion age of the rocks (Fig. 17). Also U-Pb (Silva et al., 1997) and $\mathrm{Pb}-\mathrm{Pb}$ evaporation analyses (Ledru et al., 1997) of ziron from monzonite and tonalitic orthogneisses, yielded $2126 \pm 19 \mathrm{Ma}$ and $2074 \pm 9 \mathrm{Ma}$, respectively, which are also considered to be syn-tectonic intrusion ages.

In the southern part of the Itabuna-Salvador-Curaçá belt (Figs. 2 and 3) the most important Paleoproterozoic rocks are the tonalites TT5 (Barbosa et al., 2000a; Fig. 16). They are dated at approximately $2.1 \mathrm{Ga}$. At Barra do Rocha the age found by $\mathrm{Pb}-\mathrm{Pb}$ evaporation method on zircon was $2092 \pm 13 \mathrm{Ma}$, and at Itabuna, the ages are $2130 \mathrm{Ma}$ by $\mathrm{Pb}-\mathrm{Pb}$ whole rock method, and $2.6 \mathrm{Ga}$ by the $\mathrm{Sm} / \mathrm{Nd} T_{\mathrm{DM}}$ model (Table 6 ). They are strongly foliated and sometimes banded with alternating dark green basic (pyroxene-rich) and light green intermediate (plagioclase-rich) bands.

During the Paleoproterozoic deformations, in the northern part of the Itabuna-Salvador-Curaçá belt, the Caraiba norite with an age of 2051 Ma dated by U-Pb on zircon method, and the Medrado gabbro with age of $2059 \mathrm{Ma}$ by the same method (Oliveira and Lafon, 
1995; Table 6), were emplaced. They contain copper and chromium deposits, respectively (Fig. 16). According to Silva et al. (1996) the Caraiba orebody is sill-like. Chalcopyrite and bornite occur disseminated as irregular masses or local veins, all hosted in hypersthenites, melanorites and norites, part of the sequence which also contains gabbros, gabbronorites and minor anorthosites. Chromium mineralizations occur as small to medium sized mafic-ultramafic bodies hosted in granulitic rocks. The most important is the Medrado orebody (Barbosa de Deus and Viana, 1982; Marinho et al., 1986; Silva and Misi, 1998), hosted by a tholeiitic mafic-ultramafic body, interpreted as a sill which was folded into a sinformal structure with a nearly upright axial plane and axial plunge of $20-30^{\circ}$ to the south.

\section{Paleoproterozoic metamorphism and late-tectonic rocks}

The Transamazonian high-grade metamorphism occurred at average pressures of $7 \mathrm{kbar}$ and temperaturesaround $850^{\circ} \mathrm{C}$. It is thought to result from the crustal thickening related to the tectonic superposition of the Archean blocks during the collision (Figs. 16 and 17). The metamorphic peak occurred at about 2.0 Ga (Barbosa, 1990, 1997) as suggested by: (i) radiometric dating of the Jequié migmatites (2085 \pm $222 \mathrm{Ma}$ by $\mathrm{Rb}-\mathrm{Sr}$ isochron, and $1970 \pm 136 \mathrm{Ma}$ by $\mathrm{Pb}-\mathrm{Pb}$ whole rock method; Wilson, 1987); (ii) dating of monazites from $\mathrm{Al}-\mathrm{Mg}$ granulites of Jequié block (1965-1931 Ma; Barbosa et al., 2000a); (iii) monazites ages of heterogeneous granulites from the Jequié block (2047 Ma by $\mathrm{Pb}-\mathrm{Pb}$ single zircon evaporation method; Barbosa et al., 2000b); (iv) monazite ages for a 'S' type granite of the Jequié block (2100 Ma and $2057 \pm 7 \mathrm{Ma}$ by $\mathrm{Pb}-\mathrm{Pb}$ single zircon evaporation and ion microprobe methods, respectively; Barbosa et al., 2000b); and (v) monazite ages for an $\mathrm{Al}-\mathrm{Mg}$ granulite of the Itabuna-Salvador-Curaçá belt (1996-1955 Ma by ion microprobe; Barbosa et al., 2000c). Further data related to the age of metamorphism were obtained for: (i) in situ granitic mobilizates derived from partial melting of metapelites in the Contendas-Mirante greenstone belt yield an $\mathrm{Rb}-\mathrm{Sr}$ isochron age of $2.0 \mathrm{Ga}$, fixing the age of the anatexis produced by the Transamazonic orogeny (Teixeira et al., 2000); and (ii) ${ }^{40} \mathrm{Ar}-{ }^{39} \mathrm{Ar}$ ages date the cooling after metamorphism in the Jacobina region between 1.98 and $1.93 \mathrm{Ga}$ (Cheilletz et al., 1993).

Along the northern part of Itabuna-Salvador-Curaçá belt, the metamorphism reached the granulite grade. In the transition zones between this belt and the Gavião and Serrinha blocks, new crustal environments were established in granulite, amphibolite and greenschist facies (Fig. 17). During the uplift phase, tectonic thrust ramps cut the metamorphic isograds, and megablocks of granulitic rocks were emplaced over rocks in amphibolite and greenschist facies (Fig. 17; Barbosa, 1997). At the western border of this belt, intercalated aluminous gneisses have an orthopyroxene + garnet + sapphirine mineral assemblage (Leite et al., 2000) indicating that higher $P-T$ conditions were reached in some places.

In SSE and SSW Bahia State structures in which high-grade terrains are emplaced over those of lower grade are also found (Fig. 16). In these areas, the obduction of the Itabuna-Salvador-Curaçá belt over the Jequié block transformed the Jequié rocks from amphibolite to granulite facies. Afterwards all these high-grade rocks were thrust over the Gavião block and the Contendas-Mirante greenstone belt (Fig. 16).

During the retrometamorphism at the contact between the Jequié block and the Contendas-Mirante greenstone belt, the transformation of orthopyroxene to green hornblende occurred. The presence of garnet-quartz or garnet-cordierite reaction coronae producing orthopyroxene-plagioclase simplicities, observed in the high-grade gneisses in the SSE, SSW, and NE regions, has been interpreted as an indication of pressure release. This fact reinforces the collision hypothesis, as well as the proposal of large-scale thrusting to bring blocks of rocks from deep to shallower crustal levels. $P-T-t$ diagrams elaborated for these metamorphic rocks show a clockwise metamorphic trajectory, confirming the collision context (Barbosa, 1990, 1997; Figs. 16 and 17).

Late charnockite and granite intrusions which cut all the crustal blocks are undeformed or rather weakly deformed (Figs. 16 and 17). In the northern part of the Gavião block important examples are: (i) the Campo Formoso Granite $(1969 \pm 29 \mathrm{Ma}$ and $2.6 \mathrm{Ga}$ dated by $\mathrm{Rb}-\mathrm{Sr}$ and $\mathrm{Sm}-\mathrm{Nd} T_{\mathrm{DM}}$ methods, respectively; Table 6) and (ii) other peraluminous granites, sometimes enriched in biotite, sometimes in muscovite. The 
latter, whose compositions lie close to the ternary minimum, and which have negative values of $\varepsilon_{\mathrm{Nd}}(T)$ between -13 and -5 , support the hypothesis that they were produced exclusively by crustal melting (Sabaté et al., 1990). In the southwestern part of the Gavião block, the huge undeformed Guanambi-Urandi batholith (Rosa et al., 1996) stands out. It was built by multiple intrusions composed of monzonites, syenites and granites with high-potassic geochemical signature. $\mathrm{Pb}-\mathrm{Pb}$ data on single zircon crystals give ages of 2.0-2.06 Ga which correspond to the crystallization age of the batholith, and which agrees within error limits with previous $\mathrm{Rb}-\mathrm{Sr}$ isochron data (Bastos Leal et al., 1996; Leahy et al., 1998).

In the southern part of the Itabuna-Salvador-Curaçá belt, the last transpression of the Paleoproterozoic deformation governs the emplacement of the Palestina and Mirabela layered mafic-ultramafic intrusions containing dunite, peridotite, pyroxenite and gabbro (Abram and Silva, 1992). They are undeformed and partly reequilibrated at granulite facies although igneous textures and mineral assemblages are recognized. The Mirabela body was dated by Silva et al. (1996) by the Sm-Nd method at $2.2 \mathrm{Ga}$ but, as the magma which produced this body underwent crustal contamination, this age must be considered as maximum. In the Mirabela body, a $\mathrm{Fe}-\mathrm{Ni}-\mathrm{Cu}$-bearing seam with anomalous platinum group element values is present at the peridotite-pyroxenite transition (Fig. 15). Geothermometry studies show that magmatic temperatures were above $1000^{\circ} \mathrm{C}$, and subsolidus reequilibration occurred at $850^{\circ} \mathrm{C}$ (Barbosa and Spucaia, 1996).

In the Jequie block, the dome structure of the Brejões charnockite was initially considered as a typical dome-basin interference pattern (Miranda et al., 1983; Barbosa, 1986, 1990). Mapping and satellite imagery of the Brejões-type bodies may be interpreted in terms of a diapiric regime that conditioned the emplacement into the supracrustal rocks at $2.7 \mathrm{Ga}$ (Barbosa and Sabaté, 2000, 2002; Fig. 15). However, the regionally penetrative Paleoproterozoic structures do not influence the shape of the body, and no imprint of this deformation is seen at the mesoscopic level. This suggests that the emplacement of the Brejões and neighbouring bodies may be contemporary with, or later than the Paleoproterozoic and/or Transamazonian tectonics. If this is true, the $2026 \pm 4 \mathrm{Ga}$ age
(Table 6) must correspond to the emplacement of the Brejões dome, whereas the $2.7 \mathrm{Ga}$ age may reflect the presence of inherited zircon derived from a deep crustal source (Barbosa and Sabaté, 2000, 2002; Barbosa et al., 2000b).

The major concentration of granites is in the Serrinha block. The main ones are the granites/ granodiorites of Poço Grande and Ambrósio. They have, in general, ages of about $2.0 \mathrm{Ga}$ (Table 6) and can be assumed to have originated from melting of hydrated rocks of amphibolite facies, tectonically placed under rocks of granulite facies. These granite/granodiorite diapirs of calc-alcaline affinity were emplaced into the Rio Itapicuru greenstone belt and its basement. They are elongated $\mathrm{N}-\mathrm{S}$ and have foliated margins, whereas their core are more isotropic (Matos and Davison, 1987).

It is worth mentioning that the Archean supracrustal rocks, now kinzigites, are associated to anatectic charnockites, with garnet, sillimanite, orthopyroxene, biotite, cordierite and spinel plus quartz, whoxs chemical compositions are peralkaline with $\mathrm{Na}_{2} \mathrm{O} / \mathrm{K}_{2} \mathrm{O}$ ratios higher than 1 , and which have been identified as S-type granite (Fig. 8). As they are undeformed and have ages close to $2100 \mathrm{Ma}(\mathrm{Pb}-\mathrm{Pb}$ in single zircon) and $2057 \pm 7 \mathrm{Ma}$ (monazite in electronic microprobe), they may be assumed to have formed during the metamorphic peak, after ductil deformation has ceased (Barbosa et al., 2000a,b).

Late deformations produced retrograde shear zones in the Archean blocks, and alkaline syenitic bodies were emplaced in them. The syenites intruded the granulites after these rocks had reached amphibolite facies (Fig. 17). The Itiúba massif to the north of the belt corresponds to a large $(180 \mathrm{~km} \times 15 \mathrm{~km})$ syenitic batholith, and its small equivalents to the south are the Santanápolis and São Felix bodies. Together, these intrusions form an elongated "syenite line" up to $800 \mathrm{~km}$ long near the eastern border of the Itabuna-Salvador-Curaçá belt, related to a lithospheric scale shear discontinuity (Conceição et al., 1989; Conceição, 1993). They represent an alkaline to high-K saturated magmatism and are composed of monotonous mantle-derived cumulate syenites or more diversified rock associations (Conceição, 1990; Conceição et al., 1999). The emplacement of these intrusions took place between 2.14 and $2.06 \mathrm{Ga}$, as supported by the $\mathrm{Rb}-\mathrm{Sr}$ data from Itiúba and San- 
tanapolis bodies, respectively (Conceição, 1990), in agreement with a $\mathrm{U}-\mathrm{Pb}$ zircon age $(2.1 \mathrm{Ga})$ for the latter (Conceição et al., 1999). A Sm-Nd $T_{\mathrm{DM}}$ model age for the Itiuba syenite yielded $2.6 \mathrm{Ga}$ (Sato, 1998).

\section{Tectonic correlation with the Congo-Gabon Craton (Africa)}

In the paleotectonic scenario of western Gondwana part of the São Francisco Craton exhibits remarkable geological similarities with the formerçy contiguous Congo-Gabon craton, particularly for the Archean and Paleoproterozoic evolution.

The oldest terranes of the Congo-Gabon craton comprise amphibolite and granulite grade rocks have radiometric ages between 3.0 and $2.6 \mathrm{Ga}$. These rocks are partially overlain by supracrustal belts that include volcanic and sedimentary components, folded and metamorphosed during the Eburnian (Transamazonian) Orogeny. The scenario has led to comparisons between the Congo-Gabon basement rocks with a part of the Jequié granulitic terrane and the Paleoproterozoic supracrustal belts of the São Francisco Craton (Figueirêdo, 1989).

In the Congo-Gabon craton, the Paleoproterozoic evolution of the West Central African Belt (Feybesse et al., 1998) conforms to an accretionary model from 2.5 to $2.0 \mathrm{Ga}$, which is similar in many aspects to that presented here for part of the São Francisco Craton. Lithological associations having approximately the same age are present in both cratons, indicating similar geodynamic conditions. This suggests that the major convergence of Archean continental segments and Paleoprotorozoic terranes took place at approximately $2.0 \mathrm{Ga}$. A rough symmetry of structure and and dynamics can be observed: the Congo-Gabon craton presents an eastward vergence (Ledru et al., 1994; Feybesse et al., 1998) the general vergence of the terranes of this part of the São Francisco Craton indicates westward transport.

The main axial zone of symmetry seems to be the granulite domain of the Itabuna-Salvador-Curaçá belt. The Archean Gavião (Brasil) and the Chaillu (Africa) blocks occupy symmetric and analogous positions in the accretionary build-up, both acting as uplifted crustal segments. Therefore, they induced development of the Jacobina-Contendas and Francevil- lian basins also in symmetric positions. Moreover, subduction of the continental crust led to crustal thickening of both Paleoproterozoic units. The collision tectonics developed from 2.17 to $1.90 \mathrm{Ga}$ in the São Francisco Craton, and from 2.15 to $2.04 \mathrm{Ga}$ in the Congo-Gabon craton, with analogous progressive evolution of deposits and concomitant tectonics in the basins.

\section{Final remarks and tectonic synthesis}

To achieve a reasonable interpretation of the general evolution of the plutonic and metamorphic terrains in consideration, we now summarize results and correlations showing the independent evolution of each of the Archean blocks.

The main evolution of the Gavião block took place between 3.5 and $3.0 \mathrm{Ga}$, and consists of successive emplacements of plutonic series with a periodicity between 100 and $200 \mathrm{Ma}$. Their conditions of generation suggest that important crustal thickening, probably related to thrust tectonics rather than horizontal shortening, took place. Plutonic rocks are juvenile and their genesis follows a two-stage model but contribution of older crustal material $(3.7 \mathrm{Ga})$ in the sources are detected. The Archean tectonic history is mostly obliterated by the superimposed Transamazonian tectonics. Nevertheless, during the period 2.9-2.7 Ga, plutonic and volcanic markers indicate that the Gavião protocontinent was also affected by tectonetamorphic processes during the construction of the Jequié block.

The Jequié block was built up in a different geotectonic environment. In contrast to the Gavião block which is essentially composed of TTG suites, the rocks of the Jequié block have calc-alkaline signatures which indicate the occurrence of a mantle contribution under hydrated conditions to generate this series. Accreted continental terrains passed through thermodynamics conditions corresponding to the granulite facies. This implies a important thickening which resulted from the sub-horizontal thrusting that occurred in the region. All structural and kinematic markers indicate that the thrusting was westwards. Roots of the corresponding terrains may be found in the area now occupied by the Itabuna-Salvador-Curaçá belt. All these tectonic processes occur during the Transamazonian Cycle, and obliterate previous Archean tectonic structures. 
It is difficult to distinguish the stages of Archean tectonic evolution of the Serrinha block, since evidence for this phase of evolution of this continental segment have been obscured. Preserved structures result from the early episodes of the Transamazonian orogeny. The last increments of the E-W shortening, dated at $2.1 \mathrm{Ga}$, occurred close the build-up of the Rio Itapicuru greenstone belt. Later episodes in the southern part of the Serrinha block were controlled by the blocking of transpressive mechanisms producing northwards thrusting of the Itabuna-Salvador-Curaçá belt over the Serrinha block, and related dextral shear zones developed in the Serrinha block.

In the region of the Contendas-Jacobina lineament, the structural evidence for the Paleoproterozoic collision may be divided into several successive deformation increments. These are marked by horizontal thrusts and tectonic imbrications which show a westward propagation of the tectonics and contemporaneous sedimentation in a westward foreland basin constituting the volcano-sedimentary belts.

During the Paleoproterozoic Transamazonian Orogeny, these four crustal segments collided, resulting in the formation of an important mountain belt. Geochronological constraints indicate that the regional metamorphism resulting from crustal thickening associated with the collision process took place around $2.0 \mathrm{Ga}$.

\section{Acknowledgements}

We acknowledge the fellowship from $\mathrm{CNPq}$, the agreement CNPq/IRD, the support from CBPM, and the revision of the manuscript by Edson Sampaio (Prof. IG-UFBSA, Salvador), Reinhard A. Fuck (Prof. UnB, Brasilia), Geol. Alain Vauchez (Lab. Tectonophysique, Montpellier) as well as Geol. Paulo Henrique Costa for the English revision.

\section{References}

Abram, M.B., Silva, M.G. 1992. O Corpo máfico-ultramáfico da Fazenda Mirabela, Ipiaú-BA-Química Mineral, Litogeoquímica e Evolução Petrogenética. In: Congr. Bras. Geol. 37, São Paulo, Brazil Ext. Abstr. SBG.1 pp. 449-450.

Alibert, C., Barbosa, J.S.F., 1992. Âges U-Pb déterminés à la "SHRIMP" sur des zircons du Complex de Jequié, Craton
São Francisco, Bahia, Brésil. In: 14 Réun. Sci. Terre Abstr., Toulouse, France, p. 4.

Almeida, F.F.M., 1977. O Craton do São Francisco. Rev. Bras. Geoc. 7, 349-364.

Alkmim, F.F., Brito Neves, B.B., Castro Alves, J.A., 1993. Arcabouço tectônico do Craton do São Francisco-Uma revisão. In: Dominguez, J.M.L., Misi, A. (Eds.), O Craton do São Francisco. SBG, SGM, CNPq. Bahia, Brazil, pp. 45-62.

Barbosa, J.S.F., 1986. Constitution Lithologique et Metamorphique de la Région Granulitique du Sud de Bahia (Brésil). Ph.D. Thesis. Pierre et Marie Curie University, Paris, França, 401 pp.

Barbosa, J.S.F., 1990. The granulites of the Jequié complex and Atlantic Mobile Belt, Southern Bahia, Brazil—an expression of Archean Proterozoic plate convergence. In: Vielzeuf, D., Vidal, P.H. (Eds.), Granulites and Crustal Evolution. Springer-Verlag, Clermont Ferrand, France, pp. 195-221.

Barbosa, J.S.F., 1992. Modelos geotectônicos do sul da Bahia. In: Simp. Reg. Geol. Bahia-Sergipe, Abstr. SBG. 1, pp. 92-95.

Barbosa, J.S.F., 1997. Sintese do conhecimento sobre a evolução geotectônica das rochas metamórficas Arqueanas e Paleoproterozoicas do embasamento do Craton do S. Francisco na Bahia. Rev. Bras. Geoc. 27 (3), 241-256.

Barbosa, J.S.F., Dominguez, J.M.L., 1996. Texto Explicativo para o Mapa Geológico do estado da Bahia ao Milionésimo. SICM/SGM, Salvador, Bahia, Brasil, 400 pp.

Barbosa, J.S.F., Fonteilles, M., 1989. Caracterização dos Protólitos da Região Granulítica do Sul da Bahia-Brasil. Rev. Bras. Geoc. 19 (1), 3-16.

Barbosa, J.S.F., Sabaté, P., 2000. Geological and geochronological features and the Paleoproterozoic collision of the four Archean crustal segments of the São Francisco Craton, Bahia, Brazil. In: Special Simposium-D. Structure of the Lithosphere and Deep Processes. Session D-2, Multidisciplinary Studies of Key Crustal-Scale Features. In: Int. Geol. Congr. 31, Rio de Janeiro, CD-ROM.

Barbosa, J.S.F., Sabaté, P., 2002. Geological features and the Paleoproterozoic collision of the four Archean crustal segments of the São Francisco Craton Bahia, Brazil. A synthesis. Anais. Acad. Bras. Ciências 74 (2), 343-359.

Barbosa, J.S.F., Sapucaia, N.S., 1996. Os Corpos MáficosUltramáficos da Região de Ipiaú-Bahia e suas Encaixantes Granulitizadas. In: Congr. Bras. Geol. 39, Salvador, Brazil, Abstr. 6, pp. 279-285.

Barbosa, J.S.F., Marinho, M.M., Sabaté, P., 1994. Geology of the Jequié-Itabuna granulitic belt. In: Figueirêdo, M.C.H., Pedreira, A.J. (Eds.), Petrological and geocronologic evolution of the oldest segments of the São Francisco Craton, Brazil. Bol. IG-USP 17, pp. 9-36.

Barbosa, J.S.F., Nicollet, C., Kienast, J.R., Fornari, A., 2000a. Archean Al-Mg granulites with hercinite and quartz, Jequié Complex, Bahia, Brazil. In: Int. Geol. Congr. 31, Rio de Janeiro, Brazil, CD-ROM.

Barbosa, J.S.F., Martin, H., Peucat, J.J., 2000b. Archean vs. Paleoproterozoic crustal evolution of the Laje, Mutuipe, Brejões and Santa Inês Region, Jequié Complex, Bahia, Brazil. In: Int. Geol. Congr. 31, Rio de Janeiro, Brazil, CD-ROM.

Barbosa, J.S.F., Kienast, J.R., Leite, C.M.M, 2000c. Sapphirinebearing $\mathrm{Al}-\mathrm{Mg}$ Gneisses, Itabuna Belt, Bahia, Brazil. In: Int. Geol. Congr. 31, Rio de Janeiro, Brazil, CD-ROM. 
Barbosa de Deus, P., Viana, J.S., 1982. Distrito cromitífero do Vale do Rio Jacurici. In: Congr. Bras. Geol. 32, Salvador. Soc. Bras. Geol. Excursion Guide, pp. 44-60.

Barker, F., Arth, J.G., 1976. Generation of trondhjemitic-tonalitic liquids and archean bimodal trondhjemite basalt suites. Geology 4, 596-600.

Bastos Leal, L.R., 1998. Geocronologia U/Pb (SHRIMP), ${ }^{207} \mathrm{~Pb} /{ }^{206} \mathrm{~Pb}, \mathrm{Rb} / \mathrm{Sr}, \mathrm{Sm} / \mathrm{Nd}$ e K/Ar dos Terrenos GranitoGreenstone do Bloco do Gavião: Implicações para a Evolução Arqueana e Paleoproterozoica do Craton do São Francisco, Brasil. Ph.D. Thesis. São Paulo University, 178 pp.

Bastos Leal, L.R.B., Teixeira, W., Macambira, M.J.B., Cordani, U., Cunha, J.C., 1996. Evolução crustal dos terrenos TTGs arqueanos do Bloco do Gavião, Craton do São Francisco, Geocronologia U-Pb Shrimp e $\mathrm{Pb}-\mathrm{Pb}$ em zircões. In: Cong. Bras. Geol. 32, Salvador. Soc. Bras. Geol. Abstr. 6, pp. 539-541.

Brito, R.S.C., 1984. Geologia do sill estratificado do Rio Jacaré. In: Congr. Bras. Geol. 33, Rio de Janeiro, Soc. Bras. Geol. Abstr. 9, pp. 4316-4334.

Cheilletz, A., Ferraud, G., Giuliani, G., Ruffet, G., 1993. Emerald dating through ${ }^{40} \mathrm{Ar}-{ }^{39} \mathrm{Ar}$ step-heating and laser spot analysis of syngenetic phlogopite. Earth Planet. Sci. Lett. 120, 473-485.

Conceição, H., 1990. Pétrologie du massif syénitique d'Itiuba, contribution à l'etude minéralogique des roches alcalines dans l'Etat de Bahia (Brésil). Ph.D. Thesis. Paris Sud University, Orsay, France, 393 pp.

Conceição, H., 1993. Sienitos do Estado da Bahia: Um Epítome do Tema e Interpretação à Luz do Conhecimento Atual. In: Dominguez, J.M.L., Misi, A. (Eds.), O Craton do São Francisco, SBG/SGM/CNPq, Salvador, pp. 52-55.

Conceição, H., Sabaté, P., Alonso, M.D., Bonin, B., 1989. Mise en evidence d'un controle de la mise en place du massif syenitique d'age proterozoique inferieur d'Itiuba (Bahia, Brésil). C.R. Acad. Sci. Paris 309, 403-408.

Conceição, R.V., Rosa, M.L.S., Nardi, L.V., Conceição, H., Lafon, J.M., Soliani, E., Oberli, F., Maier, M., Martin, H., 1999. Geochronology and isotopic signature of the Paleoproterozoic Santanápolis syenite (Bahia, Brazil). In: Second South American Symposum on Isotope Geology, Cordoba, Argentina, Actas, pp. 178-171.

Cordani, U.G., 1973. Evolução Geológica Precambriana da Faixa Costeira do Brasil entre Salvador e Vitória. Thesis. University of São Paulo, Brazil, 80 pp.

Cordani, U.G., Sato, K., Nutman, A., 1999. Single zircon SHRIMP determination from Archean tonalitic rocks near Uauá, Brazil. In: Second South American Symposium on Isotope Geology, Córdoba, Argentina, Actas, pp. 27-30.

Correa Gomes, L.C., 2000. Evolução dinâmica da zona de cisalhamento neoproterozóica de Itabuna-Itaju do Colonia e do magmatismo fissural alcalino associado (SSE do Estado da Bahia, Brasil). Doctor Thesis. Universidade Estadual de Campinas, $362 \mathrm{pp}$.

Couto, P.A., Delgado, I.M., Mascarenhas, J.de F., Batista, M.B., Pedreira, A.J., Siqueira, L.P., Bruni, D.C., Gonçalves, G.D., Sampaio, A.R., Gil, C.A., Loureiro, H.S., Awdziej, J., Arcanjo, J.B., Fernandes Filho, J., Guimarães, J.T., Silva, L.C., Melo, R.C., Toledo, L.A.A., Machado, G.J., Maron, J.E., Oliveira, J.E., Rodrigues, V., Frana, F.B., Teixeira, A.J., Silva, H.P.,
Margalho, R., Brito, P.C., Kipper, D., Cas, M.G., Bani, R., 1978. Projeto Serra de Jacobina-Geologia e Prospecção Geoquímica. Convênio DNPM/CPRM. Salvador, CPRM, Final Rapport 12v.

Cruz, M.J.M., 1989. Le massif de Rio Piau: une intrusion de nature gabbroique et anorthositique dans les terrains granulitiques du noyau Jequié, Bahia, Brésil. Ph.D. Thesis. Université Pierre et Marie Curie, Françe, 280 pp.

Cruz, M.J.M., Sabaté, P., 1995. Existence d'un episode intrusif anorthositique au paleoprotérozoique dans les Provences Archeennes de Bahia et d'Angola. In: Géodynamique du Paléoprotérozoique, BRGM, Soc. Géol. France, Orleans, p. 13.

Cruz, M.J.M., Lima, M.M.J., 1998. Maciço Intrusivos Gabro-Anortosítico da Samaritana: Aspectos Geológicos, Mineraloquímicos e Geoquímicos de uma intrusão toleiítica no Cinturão Itabuna, Sul da Bahia. In: Conceição, H. (Ed.), Contribuição ao Estudo dos Granitos e Rochas Correlatas. Salvador, Soc. Bras. Geol. Esp. Publ. 5, pp. 115-128.

Cruz, M.J.M., Sabaté, P., Bordini, R.M., Froes, R.J.B., 1999. Afinidades geoquímicas dos corpos gabbro-anortosíticos da interfácie do bloco Jequié com o Cinturão Itabuna/Costa Atlântica (Craton do São Francisco, Bahia, Brasil). In: Congresso de Geoquímica, 7 and Congresso de Geoquímica dos Países de Língua Portuguesa 3. Porto Seguro, Bahia, Brasilm, Abstracts, pp. 539-540.

Cunha, J.C., Fróes, R.J.B., 1994. Komatiítos com textura "spinifex" do Greenstone Belt de Umburanas, Bahia, Salvador. CBPM Special Publication, 29 pp.

Cunha, J.C., Bastos Leal, L.R., Fróes, R.J.B., Teixeira, W., Macambira, M.J.B., 1996. Idade dos Greenstone Belts e dos Terrenos TTGs Associados da Região do Cráton do São Francisco (Salvador, Bahia, Brasil). In: Congr. Bras. Geol. 29, Soc. Bras. Geol. Abstr. 1, pp. 62-65.

Evensen, N.H., Hamilton, P.J., O’Nions, R.K., 1978. Rare earth abundances in chondritic meteorite. Geochim. Cosmochim. Acta 42, 1119-1212.

Feybesse, J.L., Johan, V., Triboulet, C., Guerrot, C., Mayaga Mikolo, F., Bouchot, V., Eko N'dong, J., 1998. The West Central African Belt, a model of 2.5-2.0 Ga accretion and two-phase orogenic evolution. Precambrian Res. 87 (3/4), 161-216.

Figueirêdo, M.C.H., 1981. Geoquímica das rochas metamórficas de alto grau do nordeste da Bahia, Brasil Geologia e Recursos Minerais do Estado da Bahia. Spec. Publ. SGM/CPM 4, 1-17.

Figueirêdo, M.C.H., 1989. Geochemical evolution of eastern Bahia, Brazil: A probably Early Proterozoic subduction-related magmatic arc. J. S. Am. Earth Sci. 2 (2), 131-145.

Fornari, A., 1992. Petrologia, geoquimica e metamorfismo das rochas enderbíticas-charnockíticas da in the SSE and SSW of Bahia State região de Lage e Mutuipe, Bahia. Mast Thasis. Curso de Pós-Graduação em Geologia, Instituto de Geociências, UFBA, 143 pp.

Galvão, C.F., Santana, E.A.N., Cunha, J.C., Monteiro, M.D., Mota, P.R.P., 1981. Rio Jacaré Project. CBPM, Salvador, Final Rapport, $71 \mathrm{pp}$.

Gama, H.B., 1982. Serra de Jacobina gold-bearing metasedimentary sequence paleoplacer gold deposits. International Symposium on Archean and Early Proterozoic Geological Evolution and Metallogenesis (ISAP), Salvador, Excursion Guide, pp. 129-132. 
Garrels, R.M., Mackenzie, F.T., 1971. Evolution of Sedimentary Rocks. Norton, Inc., New York, 307 pp.

Gomes, R.A.A.D., Arcanjo, J.B.A., Reginaldo A.S., 1991. Colisão de blocos com subducção na costa sul da Bahia. In: Int. Congr. Brazilian Geophys. Soc. Salvador, Ext. Abstr. 1, pp. 154-159.

Horscroft, F.D., Molinari, L., Barbosa, C.C., 1989. The Jacobina gold mine. In: Int. Geoch. Expl. Symp. 13, Rio de Janeiro, Soc. Bras. Geoq. Excursion Guide, pp. 57-61.

Irvine, T.N., Baragar, W.R.A., 1971. A guide to chemical classification of the common volcanic rocks. Can. J. Earth Sci. $8,523-584$.

Leahy, G.A.S., Conceição, H., Rosa, M.L.S., Macambira, M.J.B., Martin, H., Paim, M.M., Santos, E.B., Bastos Leal, L.R., 1998. Maciço Sienítico de Ceraima (Sudoeste da Bahia: Idade, petrografia e geoquimica do magmatismo pós-orogênico alcalino potássico com afinidade lamprofírica. In: Conceição (Ed.), Contribuição ao Estudo dos Granitos e Rochas Correlatas. Soc. Bras. Geol. Nucleo Ba-Se. Spec. Publ., pp. 1-77.

Leite, C.M.M., Sabaté, P., Nicollet, C., Kienast, J.R., Barbosa, J.S.F., 2000. The phlogopite-spinel-sapphirine bearing Al-Mg granulites from Salvador-Curaçá Belt, Bahia, Brazil: An example of ultra-high temperature metamorphism with phlogopitestability. In: Int. Geol. Congr. 31, Rio de Janeiro, Brazil, CD-ROM.

Ledru, P., Cocherie, A., Barbosa, J.S.F., Johan, V., Onstott, T., 1994. Âge du Métamorphisme Granulitique dans le Craton du São Francisco (Brésil) Implications sur la Nature de l'Orogène Transmazonien. C.R. Acad. Sci. Paris 211, 120-125.

Ledru, P., Milési, J.P., Johan, V., Sabaté, P., Maluski, H., 1997. Foreland basins and gold-bearing conglomerates: a new model for the Jacobina Basin (São Francisco Province, Brazil). Precambrian Res. 86, 155-176.

Leo, G.M., Cox, D.P., Carvalho, J.P.P., 1964. Geologia da parte sul da Serra da Jacobina, Bahia, Brasil, Rio de Janeiro, Brazil. DNPM/DGM, Bull. 209.

Machado, R., 1977. Geologia e Gênese do Depósito de manganês de Bandarra, Município de Jacaraci, Bahia. Master's Thesis. IG/USP University, 109 pp.

Marinho, M.M., 1991. La Séquence Volcano-Sedimentaire de Contendas-Mirante et la Bordure Occidentale du Bloc Jequié (Cráton du São Francisco-Brésil): Un exemple de Transition Archéean-Protérozoique. Ph.D. Thesis. Blaise Pascal University, Clermont Ferrand, França. 388 pp.

Marinho, M.M., Sabaté, P., 1982. The Contendas-Mirante volcano-sedimentary sequence and its granitic-migmatitic basement. In: International Symposium on Archean and Early Proterozoic Geologic Evolution and Metalogenesis (ISAP), SME/CPM, Salvador, Excursion Guide, pp. 139-184.

Marinho, M.M., Rocha, G.F., Barbosa de Deus, P., Viana, J.S., 1986. Geologia e potencial cromitifero do vale do Jacurici-Bahia. In: Congr. Bras. Geol. 34, Goiânia. Soc. Bras. Geol. Abstr. 5, 2074-2088.

Marinho M.M., Sabaté, P., Barbosa, J.S.F., 1994 a. The Contendas - Mirante volcano-sedimentary belt. In: M.C.H. Figueirêdo \& A J. Pedreira (Eds.), Petrological and geocronologic evolution of the oldest segments of the São Francisco Craton, Brazil. Bull. IG-USP, 17, 37-72.
Marinho M.M., Vidal, Ph., Alibert, C., Barbosa, J.S.F., Sabaté, P., 1994 b. Geochronology of the Jequié-Itabuna granulitic belt and the Contendas Mirante volcano-sedimentary belt. In: M.C.H. Figueirêdo \& A J. Pedreira (Eds.), Petrological and geocronologic evolution of the oldest segments of the São Francisco Craton, Brazil. Bull. IG-USP, 17, 73-96.

Martin, H., 1994. The Archaean grey gneisses and the genesis of continental crust. In: Condie, K.C. (Ed.), The Archean Crustal Evolution. Elsevier, pp. 205-259.

Martin, H., Sabaté, P., Peucat, J.J., Cunha, J.C., 1991. Un Segment de Croute Continentale d'Áge Archéean Ancien (3.4 milliards d'années): le Massif de Sete Voltas (Bahia-Brésil). C.R. Acad. Sci. Paris 313, 531-538.

Martin, H., Peucat, J.-J., Sabaté, P., Cunha, J.C., 1997. Crustal evolution in Early Archaean of South America: example of the Sete Voltas Massif, Bahia, Brazil. Precambrian Res. 82, 35-62.

Mascarenhas, J de F., Alves da Silva, E.F., 1994. Greenstone Belt de Mundo Novo (Ba): Caracterização e Implicações Metalogenéticas no Cráton do São Francisco. CBPM Final Rapport, $32 \mathrm{pp}$.

Mascarenhas, J. de F., 1969. Estudo geológico da parte norte da Serra de Jacobina, Bahia, Brasil. Precambrian Res. 82, 35-62.

Mascarenhas, J. de F., Conceição Filho, V.M., Griffon, J.C., 1992. Contribuição à Geologia do Grupo Jacobina na Região Jacobina/Pindobaçu. In: Congr. Bras. Geol. 37. Ext. Abstr. Soc. Bras. Geol. 2, pp. 141-142.

Matos, F.M.V., Davison, I., 1987. Basement or intrusion? The Ambrósio dome, Rio Itapicuru greenstone belt Bahia Brazil. Rev. Bras. Geoc. 17, 442-449.

Mello, E.F., Xavier, R.P., Mcnaughton, N.J., Fletcher, I., Hagemann, S., Lacerda, C.M.M., Oliveira, E.P., 2000. Age constraints of felsic intrusions, metamorphism, deformation and gold mineralization in the paleoproterozoic Rio Itapicuru greenstone belt, NE Bahia State, Brazil. In: Int. Geol. Congr. 31 Abstr. Vol., Special Symposium 18.4-Stable and Radiogenic Isotopes in Metallogenesis, CD-ROM.

Milesi, J.P., Ledru, P., Marcoux, E., Mougeout, R., Johan, V., Lerouge, C., Sabaté, P., Bailly, L., Respaut, J.P., 2001. The Jacobina paleoproterozoic gold-bearing conglomerates, Bahia, Brazil: a "hydrothermal shear-reservoir model". Ore Geol. Rev. 19, 95-136.

Miranda, L.L. de, Moraes, A.M.V., Cruz, M.J.M., Silva, E.C.J., 1983. Jequié-Boa Nova Project. Salvador, CBPM/SME/CBPM, $5 \mathrm{v}$.

Molinari, L., 1983. Mineralizações auríferas em Jacobina, Bahia. In: Simp. Mineral. Aurif. Estado da Bahia, Salvador, Soc. Bras. Geol., Abstr., pp. 26-31.

Molinari, L., Scarpelli, W., 1988. Depósitos de Ouro de Jacobina. In: Schobbenhaus, C., Coelho, C.E.S. (Eds.), Os Principais Depósitos Minerais do Brasil, vol. 3, pp. 463-478.

Mougeot, R., 1996. Etude de la limite Archéen-Protérozoique et des mineralisations $\mathrm{Au}, \pm \mathrm{U}$ associées. Exemples de la région de Jacobina (Etat de Bahia, Brésil) et de Carajas (Etat de Para, Brésil). Ph.D. Thesis. Montpellier II University, France, 301 pp.

Nutman, A.P., Cordani, U.G., 1993. SHRIMP U-Pb zircon geochronology of Archean granitoids from the Contendas-Mirante area of the São Francisco Craton, Bahia, Brazil. Precambrian Res. 63, 179-188. 
Nutman, A.P., Cordani, U.G., Sabaté, P., 1994. SHRIMP $\mathrm{U}-\mathrm{Pb}$ ages of detrital zircons from the Early Proterozoic Contendas-Mirante supracrustal belt, São Francisco Craton, Bahia, Brazil. J. S. Am. Earth Sci. 7, 109-114.

Oliveira, E.P., Lafon, J.M., 1995. Age of ore-rich Caraíba and Medrado. Bahia, Brazil. In: Congr. Bras. Geoq., CD-ROM.

Oliveira, E.P., Lafon, J.M., Souza, Z.S., 1999. Archean-Proterozoic transition in the Uauá block, NE São Francisco Craton, Brazil: $\mathrm{U}-\mathrm{Pb}, \mathrm{Pb}-\mathrm{Pb}$ and $\mathrm{Nd}$ isotope constraints. In: Simpósio Nacional de Estudos Tectônicos, Lençóis, Bahia, Brazil. Abstr. 7, pp. 38-40.

Padilha, A.V., Melo, R.C., 1991. Estruturas e Tectônica. In: Programe de Levantamentos Geológicos Básicos do Brasil (PLGB); Folha SC.24-Y-D-V, Pintadas, Estado da Bahia. DNPM, Brasilia, Convênio DNPM/CPRM, vol. 3, pp. 49-54.

Pearce, T.H., Gorman, B.E., Birket, T.C., 1975. The $\mathrm{TiO}_{2}-\mathrm{K}_{2} \mathrm{O}-\mathrm{P}_{2} \mathrm{O}_{5}$ diagram: a method of discrimination between oceanic and non-oceanic basalts. Earth Planet. Sci. Lett. 24, 419-426.

Peucat, J.J., Mascarenhas, J.de F., Barbosa, J.S.F., Leal de Souza, S., Marinho, M.M., Fanning, C.M., Leite, C.M.M., 2002. 3.3 Ga SHRIMP U-Pb zircon age of a felsic metavolcanic rock from the Mundo Novo greenstone belt 2000. In the São Francisco Craton, Bahia (NE Brazil). J. S. Am. Earth Sci. 15, 363-373.

Ribeiro Filho, E., 1968. Geologia da Região de Urandi e das Jazidas de Manganês Pedra Preta, Barreiro dos Campos e Barnabé, Ba. Ph.D. Thesis. Fac. Fil. Ciências e Letras, USP, São Paulo, Brazil, 82 pp.

Rios, D.C., 2002. Granitogenese no Núcleo Serrinha, Bahia, Brasil: Geocronologia e Litogeoquimica. Inst. de Geociências, Universidade Federal da Bahia, Bahia, Tese de Doutoramento, $233 \mathrm{pp}$.

Rosa, M.I.S., Conceição, H., Paim, M.M., Santos, E.B., Alves da Silva, F.C., Leahy, G.A.S., Bastos Leal, L.R., 1996. Magmatismo potássico/ultrapotássico pós a tardi-orogênico (associado à subducção) no oeste da Bahia: Batólito monzo-sienítico de Guanambi-Urandi e os sienitos de Correntina. Geochim. Brasil. 10, 27-42.

Sá, J.H.S., Barbosa, J.S.F., 1990. Origem dos Depósitos de baritina de Piraí do Norte, Bahia. In: Congr. Bras. Geol. 36, Natal, Brazil, Soc. Bras. Geol, Abstr., p. 122.

Sabaté, P., Correa Gomes, L.C., Anjos, J.A.S.A.A., 1988. Mapa temático "Granitogênese da Bahia"- Folha Vitória da Conquista 1/250.000. SME/SGM, Salvador, Bahia, Brazil.

Sabaté, P., Marinho, M.M., Vidal, P., Vachette, M.C., 1990. The $2 \mathrm{Ga}$ peraluminous magmatism of the Jacobina-Contendas Mirante belts (Bahia-Brazil): geologic and isotopic constraints on the sources. Chem. Geol. 83, 325-338.

Sabaté, P., Peucat, J.J., Melo, R.C., Pereira, L.H.M., 1994. Datação por $\mathrm{Pb}$ evaporação de monozircão em ortognaisse do Complexo Caraiba. Expressão do Acrescimento Crustal Transamazônico do Cinturão Salvador-Curaçá (Craton do São Francisco-Bahia, Brasil). In: Congr. Bras. Geol. 38. So Paulo, Brazil. Soc. Bras. Geol. Ext. Abstr. 1, pp. 219-220.

Santos Pinto, M.A., 1996. Le Recyclage de la Croûte Continentale Archéene: Exemple du Bloc du Gavião-Bahia, Brésil. Ph.D. Thesis. Rennes I University, 193 pp.
Sato, K., 1998. Evolução Crustal da Plataforma Sul Americana com base na geoquímica isotópica $\mathrm{Sm}-\mathrm{Nd}$. Ph.D. Thesis. I G-USP, São Paulo, 297 pp.

Scarpelli, W., 1991. Aspect of gold mineralization in the iron quadrangle, Brazil. In: Ladeira, E.A. (Ed.), Brazil Gold 91. Balkema, Rotterdam, pp. 11-30.

Schobbenhaus, C., Coelho, C.E.S., 1986. Principais Depósitos Minerais do Brasil. MME/DNPM/CPRM. IV-C, 501 pp.

Schobbenhaus, C., Campos, D.A., Derge, G.R., Asmus, H.E., 1984. Geologia do Brasil. Texto Explicativo do Mapa Geológico do Brasil e da área oceânica adjacente, incluindo depósitos minerais. DNPM-Departamento Nacional da Produção Mineral, $501 \mathrm{pp}$.

Silva, M.G. da., 1992. Evidências Isotópicas e Geocronológicas de um Fenômeno de Acrescimento Crustal Transamazônico no Cráton do São Francisco, Estado da Bahia. In: Congr. Bras. Geol. 37, São Paulo, Brazil. Soc. Bras. Geol. 2, pp. 181-182.

Silva, M.G. da., 1996. Sequências Metassedimentares, Vulcanossedimentares e Greenstone Belts do Arqueano e Proterozoico Inferior. In: Barbosa, J.S.F., Dominguez, J.M.L. (Eds.), Geologia da Bahia: Texto Explicativo para o Mapa Geológico ao Milionésimo, SICM/SGM, Salvador, pp. 85-102.

Silva M.G. da., Martin, H., Abram, M.B., 1996. Datação do corpo máfico-ultramáfico da fazenda Mirabela (Ipiaú-Ba) pelo método Sm-Nd: Implicações petrogenéticas e geotectônicas. In: Congr. Bras. Geol. 39, Salvador, Abstr., pp. 217-220.

Silva, M.G. da, Misi, A., 1998. Embasamento ArqueanoProterozoico Inferior do Craton do São Francisco no Nordeste da Bahia. Geologia e Depósitos Minerais. Série Roteiros Geológicos. Convenio SICM/UFBA/SGM/PPPG/FAPEX, 164 pp.

Silva, L.C. da, McNaughton, R.C. deMelo, Fletcher, I.R., 1997. $\mathrm{U}-\mathrm{Pb}$ SHRIMP ages in the Itabuna-Caraiba TTG high-grade complex: the first window beyond the Paleoproterozoic overprint of the eastern Jequié Craton, NE Brazil. In: International Symposium on Granites and Associated Mineral, ISGAM, Salvador, Bahia, Brazil, Abstracts, pp. 282-283.

Silva, M.G. da, Silva Coelho, C.E., Teixeira, J.B.G., Alves da Silva, F.C., Bras de Souza, J.A., Silva, R.A., 2001. The Rio Itapicuru greenstone belt, Bahia, Brazil: geologic evolution and review of gold mineralisation. Mineralium Deposita 36, 345-357.

Sims, J.F.M., 1977. A geologia da sérire Jacobina aurífera nas vizinhaças de Jacobina, Bahia, Brasil. Semana de Estudos SIGEQ, 17, Ouro Preto Minas Gerais, Brazil Bull. 17, 223-282.

Teixeira, L.R., 1997. O Complexo Caraíba e a Suite São José do Jacuipe no Cinturão Salvador-Curaçá (Bahia-Brasil): Petrologia, Geoquímica e Potencial Metalogenético. Ph.D. Thesis. Federal da Bahia University, 201 pp.

Teixeira, L.R., Melo, R.C., 1990. Geoquímica dos ortognaisses granulíticos do Complexo Caraíba, região de Riachão de Jacuipe, Bahia. In: Congr. Bras. Geol. 36, Natal, RGN, Brazil. Soc. Bras Geol. Abstr. 6, pp. 1849-1860.

Teixeira, W., Sabaté, P., Barbosa, J.S.F., Noce, C.M., Carneiro, M.A. 2000. Archean and Paleoproterozoic Tectonic evolution of the São Francisco Craton, Brazil. In: Cordani, U.G., Milani, E.J., Thomas Filho, A., Campos, D.A. (Eds.) Tectonic Evolution of the South America. In: Int. Geol. Congr. 31, Rio de Janeiro, Brazil, pp. 101-137. 
Teixeira, J.B.G., Braz de Souza, J.A., Silva, M. da G., Barbosa, J.S.F., Leite, C.M., Coelho, E.S.C., Abram, M.B., Conceição Filho, V.M., 2001. The gold deposits of Serra de Jacobina central part, Bahia, Brazil. Mineralium Deposita 36, 332-344.

Toniatti, G., Barbosa, J.S.F., 1973. O Manganês de Maraú, Bahia. In: Congr. Bras. Geol. 37, Aracajú, Abstr. 2, pp. 421-430.

Ussami, N., 1993. Estudos geofísicos no Craton do São Francisco: estágio atual e perspectivas. In: Dominguez, J.M.L., Misi, A. (Eds.), Simpósio sobre o Craton do São Francisco, Salvador, Bahia, Brazil. SBG/SGM/CNPq. Spec. Publ., pp. 35-62.

Valarelli, J.V., Barbosa, J.S.F., Hipólito, R., Silveira, B.R.M., 1982. Paragênese do Protominério Metamórfico de Manganês de Maraú, Bahia. In: Congr. Bras. Geol. 32, Salvador, Soc. Bras. Geol., Abstr. 3, pp. 819-825.

Wilson, N., 1987. Combined $\mathrm{Sm}-\mathrm{Nd}, \mathrm{Pb} / \mathrm{Pb}$ and $\mathrm{RbSr}$ geochronology and isotope geochemistry in polymetamorphic precambrian terrains: examples from Brazil and Channel Island, U.K. Master of Science. Unpublished Master's Thesis. Oxford University, UK, $54 \mathrm{pp}$.

Winge, M., 1984. A Sequencia Vulcanossedimentar do Grupo Rio Capim, Bahia. In: Viveiro Sá, P.V.da S., Duarte, F.B. (Eds.), Geologia e Recursos Minerais do Estado da Bahia, Salvador, Brazil. SME/CPM Spec. Publ. 5, pp. 43-103. 